\title{
Cold gas spray coatings: basic principles, corrosion protection and applications
}

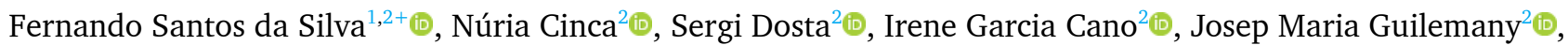
Assis Vicente Benedetti ${ }^{1}$ iD

${ }^{1}$ São Paulo State University, Institute of Chemistry, 55 Prof. Francisco Degni St., 14800-060 Araraquara, São Paulo, Brazil

2 Barcelona University, Centre de Projecció Tèrmica, Martí i Franqués 1 St., 08028 Barcelona, Spain

+ Corresponding authors: Fernando Santos da Silva, phone: +55-16-3301-9649, e-mail address: fernandoquimicauems@gmail.com Assis Vicente Benedetti, phone: +55-16-3301-9641, e-mail address: benedeti@iq.unesp.br

\section{ARTICLE INFO}

Article history:

Received: October 6, 2017

Accepted: November 15, 2017

Published: December 30, 2017

\section{Keywords:}

1. cold gas spray (CGS) coatings

2. feedstock powders

3. spray parameters

4. corrosion

5. CGS technology applications
ABSTRACT: In this review, the beginnings and evolution of the cold gas spray (CGS) technique are described, followed by the main fundamental aspects of the technique together with a description of the several spraying systems up to date. Sequentially, the main spray parameters and their influence on the properties of the coatings are reported. Afterwards, the most important methodologies for preparing the feedstock powders to be sprayed, the effect of the powder composition, microstructure, particle size and shape on the properties of the coatings are discussed. The nature of the spray gun and nozzle, and the substrate pre-treatments were also discussed. With regard to microstructure and properties, the chemical and physical characterization of the coatings and the performance in protecting the substrates against corrosion together with some mechanical properties are presented and compared. The lacking systematic studies about the great part of investigated systems is the main drawback to compare the published results. Closing this review, the main applications, and the potentialities of the CGS coatings are evidenced.

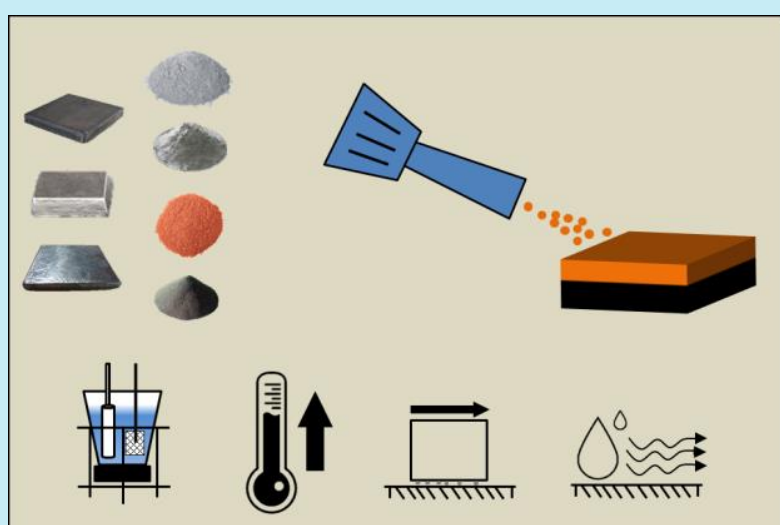

From feedstock powder to the CGS coatings resistant to high temperature, corrosion, wear and weathering.

\section{CONTENTS}

1. History of cold gas spray (CGS)

2. Fundamental principles of CGS

3. Spray parameters and other factors influencing the properties of the coating

3.1 Pressure and temperature

3.2 Spray distance

3.3 Gun transverse speed

3.4 Spray angle

3.5 Substrate temperature

3.6 Feedstock powder

3.6.1 Main processes for obtaining powders

3.6.1.1 Atomization

\subsubsection{Agglomeration and sintering \\ 3.6.1.3 Mechanical process \\ 3.6.2 Influence of composition, structure, and size of the feedstock powder \\ 3.7 Influence of spray gun and nozzle \\ 3.7.1 Spray gun \\ 3.7.2 Spray gun nozzle \\ 3.8 Substrate preparation}

4. Some relevant corrosion studies of cold spray coatings and corrosion protection

5. Applications of CGS technology

6. Concluding Remarks

7. Acknowledgments

8. References 


\section{History of cold gas spray (CGS)}

Cold Gas Spray (CGS) has recently emerged in the field of thermal spray techniques. It was developed in the mid-1980s by A. Papyrin and his team at Institute of Theoretical and Applied Mechanics of the Siberian Branch, now called Khristianovich Institute of Theoretical and Applied Mechanics in Novosibirsk city, Russia ${ }^{1-6}$. This group of scientists, studying aerodynamic systems in a supersonic wind tunnel, decided to use small particles of steel and aluminum mixture with the supersonic gas system to make a twophase (gas+solid) fluid. After the test, it was observed that particles of different sizes and sprayed at different velocities and angles were deposited onto the material surface when the fluid velocity had reached certain critical value. This process was called "Cold Spray" phenomenon $^{1-6}$. Figure 1 shows the timeline for key developments of cold gas spray processes.

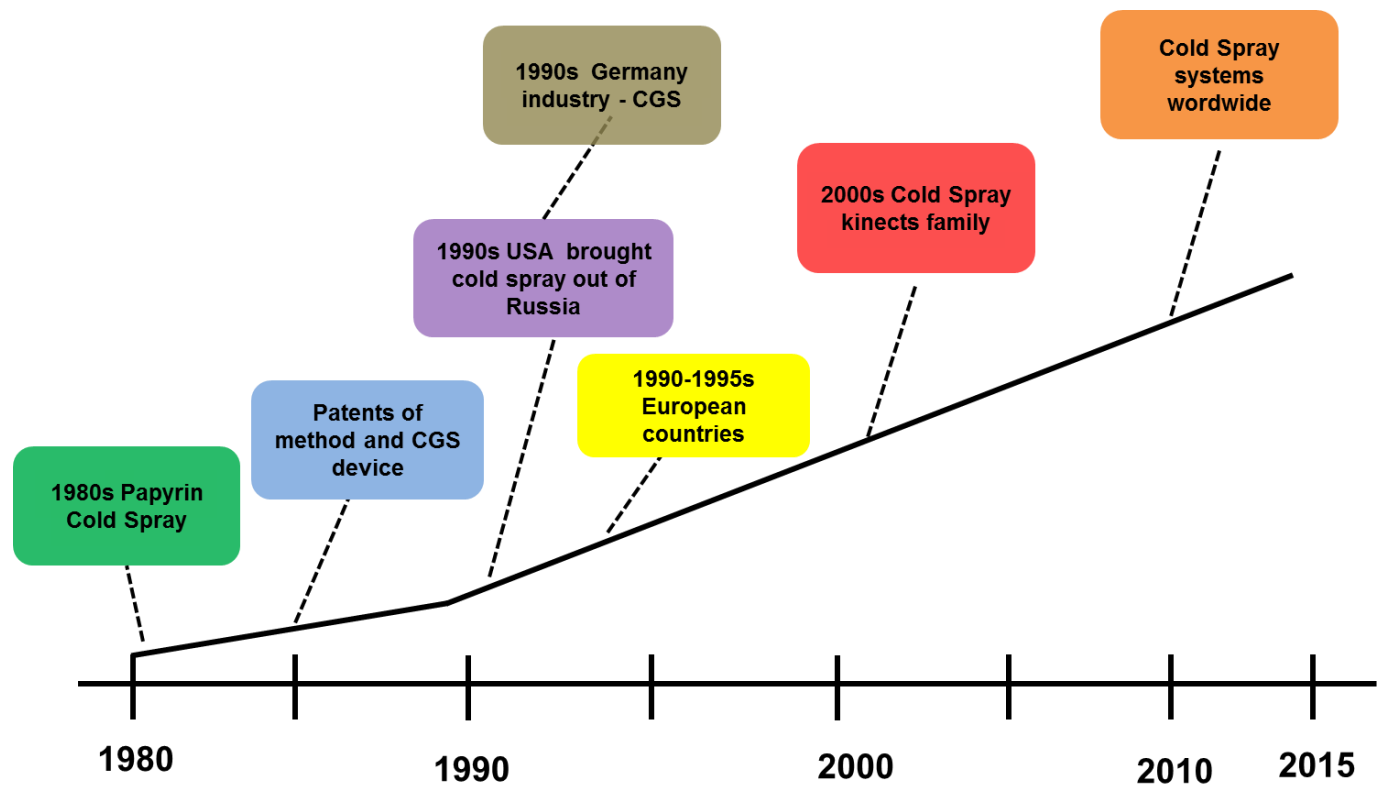

Figure 1. Timeline of Cold Gas Spray processes.

From 1986 to 1990 , this group developed two patents of the CGS equipment construction and a method for coating deposition ${ }^{1}$. From 1990 to 2000 the United States of America established a partnership with the Russian government to build the first CGS equipment. The system was made by A. Papyrin, and the US was the second country to have a Cold Gas Spray system. In the same decade, Germany and other European countries made their CGS systems and began to investigate new applications. After that, basic studies about the spray parameters and the use of many techniques to evaluate the coating formation and microstructure allowed to increase the CGS applications in the industry field ${ }^{1,3}$. After the 2000 's, the CGS process experimented great development, and significantly spread to different countries, mainly during the last years thanks to $R \& D$ actions and production efforts all over the world. A recent study ${ }^{7}$ published the state-of-art of CGS installations worldwide. The European represents 55\% of the CGS system being used for R\&D and production, USA $20 \%$, China $7 \%$ and $18 \%$ are divided by Japan, Korea,
Taiwan, India, Australian and Canada. The installations worldwide are used for R\&D activities (60\%) rather than for production $(40 \%)$. A wide spectrum of investigations is being conducted at many research centers and companies which are developing many applications. Some of them will be discussed at the section 5 of this review.

\section{Fundamental principles of CGS}

In CGS, metallic or nonmetallic materials are heated at relatively low temperatures $\left(<1000{ }^{\circ} \mathrm{C}\right)$ and accelerated between 500 and $1200 \mathrm{~m} / \mathrm{s}$, depending on the gas used, spraying parameters and nozzle design, in a high pressure supersonic gas jet that allows the particles to be plastically deformed during impact with the target to form interconnected splats adhered to the substrate $^{1,3,4,8,9}$, resulting in the coating (Figure 2). 


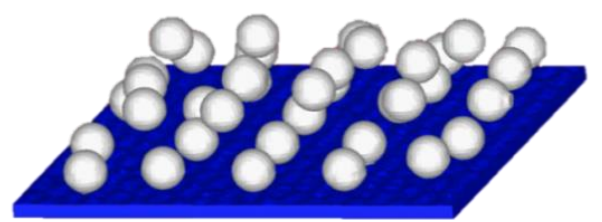

(a)

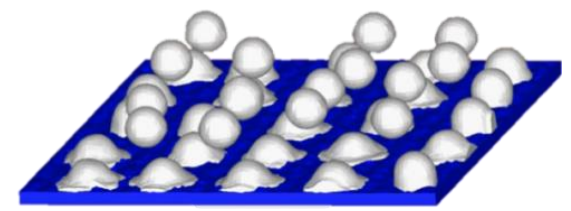

(b)

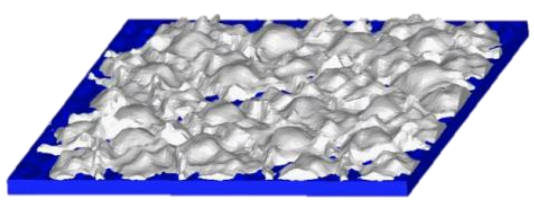

(c)

Figure 2. Process of cold gas spray coating formation: a) spraying of the particles on the surface; b) plastic deformation of the particles and c) coating formation [10].

Unlike other thermal spray techniques, the CGS uses high kinetic energy and low thermal energy for the coating deposition ${ }^{5,11,12}$ (Figure 3). Therefore, the coatings can be thicker, with lower porosity, without cracks (stresses tend to be compressive rather than tensile) and with minimum oxidation. The temperatures used during the spraying process prevent the oxidation of the feedstock material as well as thermal degradation; thus, the coatings are practically oxidesfree and chemical reactions which may lead to the formation of new phases do not occur. Figure 3 compares the temperature and the velocity of the particles used in the conventional thermal spray and CGS techniques ${ }^{2,6}$.

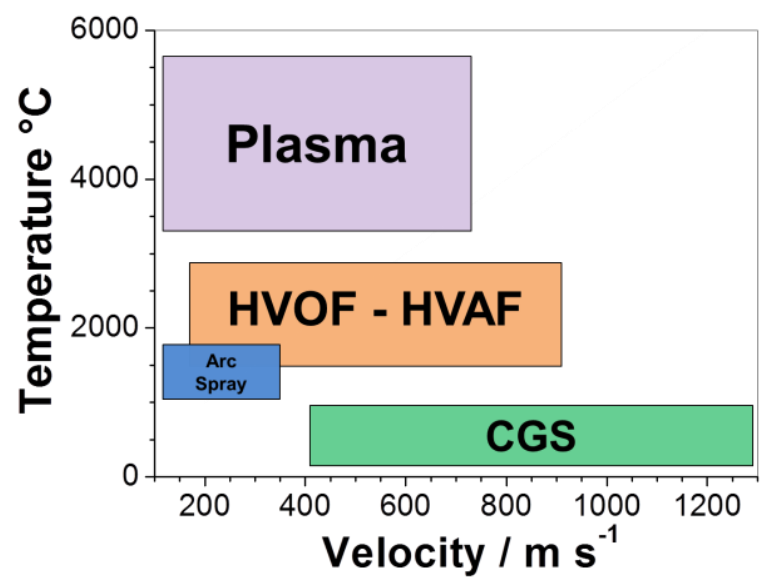

Figure 3. Classification of thermal spray processes according to particle velocity and work temperature.
There are two types of CGS equipment designs available for commercial use: low-pressure cold spray (LPCS) and high-pressure cold spray (HPCS). In Lowpressure Cold Spray (LPCS) compressed air or nitrogen can be used as spraying gas ${ }^{4}$. The gas pressure is relatively low, between 5-10 bars, and at a temperature around $550{ }^{\circ} \mathrm{C}$. In that system, the gas contained in a reservoir follows a pipeline to the heating system of the equipment where it is heated and brought to the low-pressure chamber and heating the spray gun and then forced through the convergence / divergence (Figure 4$)^{4}$. At the exit of the nozzle (divergent side), the velocity of the particles can reach between $300-600 \mathrm{~m} \mathrm{~s}^{-1}$. The solid particles are injected radially shortly after the beginning of the divergent part of the nozzle and accelerated towards the substrate ${ }^{4,12}$.

Powder feeder

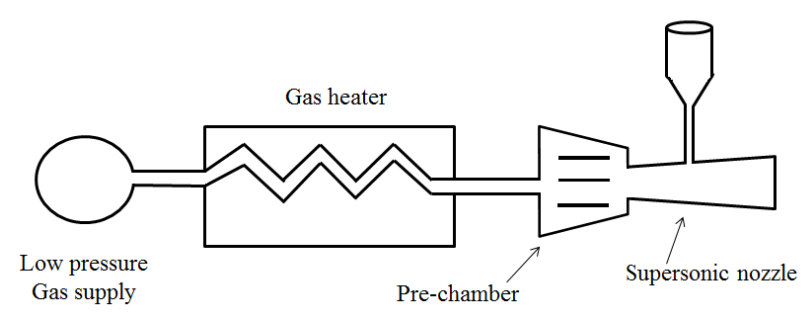

Figure 4. Low-pressure CG spraying system.

Some of the advantages of the LPCS systems are their compact size and low weight. This equipment is portable which allows the use in industrial platforms and transport without major difficulties. There is improvement on the operational safety due to the use of lower pressure. During the spraying process, the particles do not flow through the throat of the nozzle, hence wear of the nozzle walls occurs only in the supersonic portion of the nozzle and, this ensures a longer service life of the nozzle. In addition, a LPCS system is more compatible with several system modifications and cheaper than others CGS systems. However, the LPCS system shows disadvantages, for example, a low deposition efficiency when used to spray harder materials such as ceramics and some metals, e.g. titanium ${ }^{4,13}$.

The other CGS set-up commercially available is the High-pressure Cold Spray (HPCS). In HPCS, helium or nitrogen can be used as carrier gas ${ }^{4}$. The gas pressure during spraying process is ca. 25-40 bar and the working temperature can reach up to $1000{ }^{\circ} \mathrm{C}$. The solid powder feedstock particles mix with the propellant gas in the pre-chamber zone and are then axially fed into the gas stream, upstream of the converging section of the nozzle at a higher pressure than the accelerating gas to prevent backflow of the 
carrier gas to the powder feeder as shown in Figure $5^{4}$. At the exit of the nozzle (divergent side) the velocity of the particles can reach between $600-1200 \mathrm{~m} \mathrm{~s}^{-1}$. The HPCS systems are stationary and can be used for the spraying of the most diverse kinds of feedstock material with high deposition efficiency even for harder materials such as ceramics. Al-based metallic glass powder with $81 \%$ of amorphous phase was recently prepared by HPCS onto Aluminum-7075-T6 alloy with better mechanical properties and higher corrosion resistance than the substrate ${ }^{14}$.

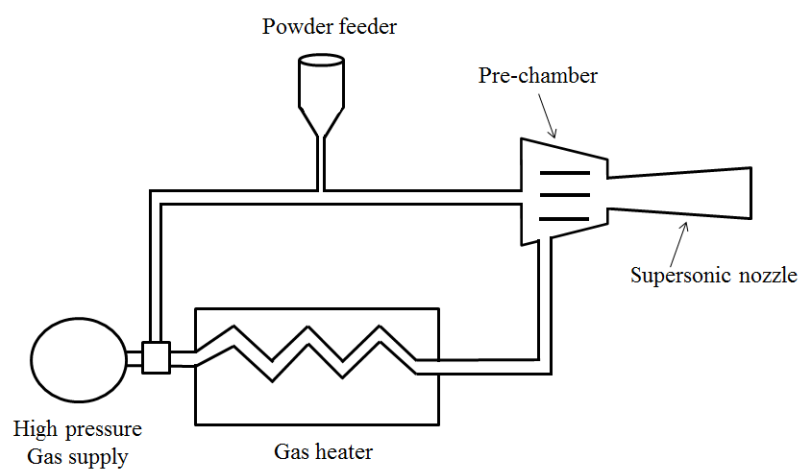

Figure 5. Scheme of the high-pressure cold spray system.

The mechanism of the CGS coating formation where the particle plastically deforms and adheres on the substrate is not yet well established and seems to depend considerably on the pair of materials and their inherent properties. It is known that when a particle is sprayed onto the substrate, its kinetic energy is transformed into strain energy and heat, which can involve an intense plastic deformation of both particle and substrate surface or mainly of one of the two; when the substrate is much harder than the particle, the particle tends to flatten while, on the reverse case, the particle tends to embed within the substrate. The process of impact tends to break thin oxide films on the substrate and particle surface, and establishes intimate contact between "clean" and chemically active surfaces, which also happens when building up the coating among particle-particle contact points. Moreover, the high pressures during spraying cause the packing of particles, and these conditions lead to a strong bonding between particles/substrate and particles/deposited material ${ }^{1,2}$. Other phenomena assigned to the adhesion of materials and coating formation relate to metallurgical bonding, as for example, interfacial fusion or diffusion of materials through different phases were studied ${ }^{1,2,15,16}$. Nevertheless, the results show that diffusion does not occur in the CGS coating formation due to the very short particle/substrate contact time scales. In CGS, the adiabatic shear instability is considered one of the dominant mechanisms to explain the strong bonding between microparticles and the substrate or the deposited layer, which is related to the abnormal strain rise and stress collapse due to the plastic deformation at the interface ${ }^{17,18}$. Using this concept, the deformation behavior was examined and critical velocities estimated $^{17-19}$. Copper is a model metal to investigate the mechanism, but its behavior is not followed by other metals because the start of material instability depends on the thermal-softening and strain-rate hardening of each material ${ }^{20}$. Drehmann et al. ${ }^{15}$ and Grigoriev et al., ${ }^{2}$ analyzing the existence of fusion at particle/substrate interface, showed that the kinetic energy to deposit the particles plus the thermal energy of the particles during the spraying process are smaller than the energy required to promote the fusion of particle/substrate interface for different coatings and substrates $^{20,21}$. The plastic deformation is also an energy dissipation process and the increase of temperature at interfacial region due to the particles deposition is not enough to allow the material diffusion between the phases ${ }^{2,8,15}$, and depending on the particle/substrate nature four interfases can be distinguished: soft / soft; hard / hard, soft / hard and hard / soft and the consequences of the different sizes of the thermal boost-up zone on the aspects of the adiabatic shear instability were discussed ${ }^{20}$. A comprehensive description of bonding in CGS process based on theoretical studies combined to experimental results led to the prediction of coating properties and opened a possibility to optimize the process parameters and nozzle geometry ${ }^{22}$. Therefore, the CGS coating formation is a solid-state process considering that the all particle is not molten, however, a very thin layer is in a so deformed condition, in which melting could occur, but it is still an open question.

The most important criterion in CGS is that material deposition takes place only if the velocity of the particles when impacting the substrate exceeds certain value, which is called critical velocity. Figure 6 schematically displays the materials deposition efficiency (DE). As the material deposition occurs only when the critical velocity is reached, a further increase of velocity leads to a steep increase in DE and may attain deposition efficiency close to $100 \%$. After reaching the highest deposition efficiency, a further increase of particle velocity makes the DE to decrease due to erosive effects of the particles penetration in the substrate or in the already deposited material ${ }^{2,22}$. 


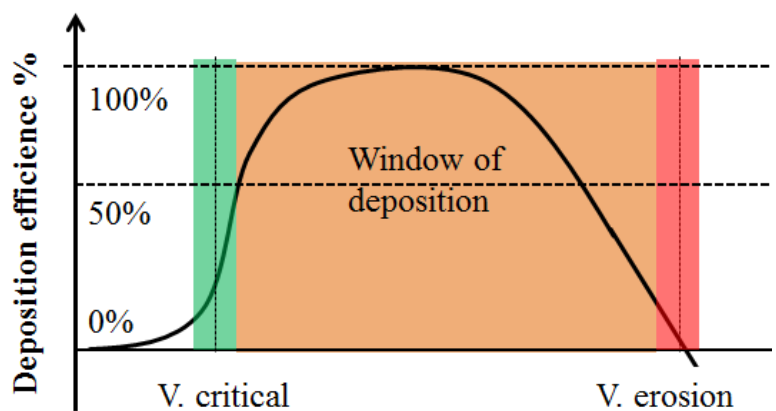

Figure 6. Schematic correlation among particle velocity, deposition efficiency (DE), and impact effects for a constant temperature.

In summary, the critical velocity is a relation among kinetic, thermal energy and physical chemical characteristics of the feedstock. Assadi et al. ${ }^{23}$ even proposed a $\eta$ parameter to build some selection maps; this is a dimensionless parameter, defined as the ratio of particle impact velocity to critical particle impact velocity. Some works ${ }^{2,3,22}$ have proposed mathematical equations to model the critical velocity behavior.

However, it has not been completely understood; it is difficult to consider the influence of the substrate within the first layer and fails at considering that real spraying involves a particle size distribution. It is wellknown that to obtain dense and compact coatings with higher deposition efficiency, the particle must reach the critical velocity. Therefore, the studying and planning in detail the spray parameters are important steps to follow before producing any CGS coating. These parameters and their importance will be discussed below.

\section{Spray parameters and other factors influencing the properties of the coating}

\subsection{Gas pressure and temperature}

Gas pressure and temperature are the main spray parameters because small changes in these parameters can produce an increase or decrease of the velocity and oxidation of the particles, characteristics that can reduce the deposition efficiency and adhesion of the coating on the substrate. The critical velocity obtained through the relationship between relative deposition efficiency and spray angle by simulation and experiments for copper is reasonable, and the increase in the particle temperature can decrease the critical velocity of the particle until $14 \mathrm{~m} \mathrm{~s}^{-1}$ each increment of $100{ }^{\circ} \mathrm{C}^{24}$. It happens because of the feedstock material becomes more ductile with increasing the temperature, consequently, can deform more easily the particles during the impact.

The higher the pressure values used, the higher the spraying velocity reached. In CGS, it is possible to work with pressures between 5-40 bar; nevertheless, a systematic study of this parameter must be performed for each system, since low pressure values may not be enough for the particles to reach the critical velocity and to form the splats (Figure $7 \mathrm{a})^{25}$. On the other hand, too high pressures may cause the particle deflection or cavitation (Figure $7 b)^{26}$ depending on the feedstock powder and substrate material characteristics, leading to decrease the deposition efficiency.
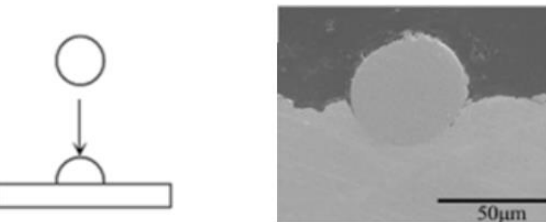
pressure

(a)
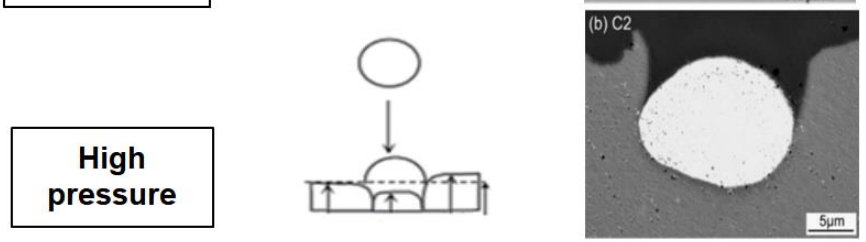

(c)
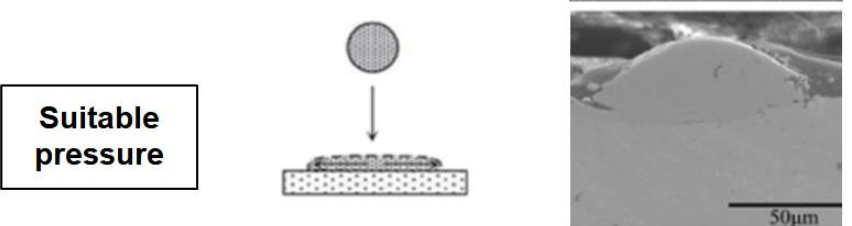

Figure 7. Correlation between pressure and splat formation. Adapted from Refs. [25,26]. Reproduced with permission. 


\subsection{Spray distance}

The spray distance is the distance between the nozzle of the spray gun and the surface of the substrate and is defined as the path that the particles travel on leaving the gun until they collide with the substrate ${ }^{27}$. The spraying distances used in CGS do not exceed 50 $\mathrm{mm}$, much smaller than those used in other spray techniques, which range from 120 to $300 \mathrm{~mm}$. This parameter can determine the speed and temperature at the point that the particle reaches the substrate, and directly influences the formation of the coating. Figure 8 depicts that increasing the spray distance, the deposition efficiency of the coatings decreases regardless of the sprayed material characteristics ${ }^{28}$.

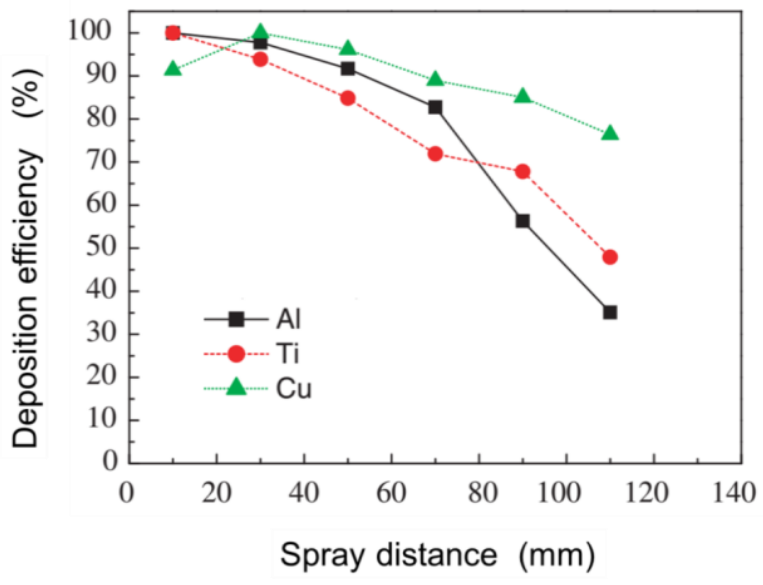

Figure 8. Influence of spray distance on deposition efficiency of the coating. Adapted from ref. ${ }^{28}$ with permission.

\subsection{Gun transverse speed}

The gun transverse speed defines the amount of material that will be deposited ${ }^{27}$. For a defined number of passes, a slow gun transverse speed implies a larger amount of deposited material. A higher gun transverse speed will cause the opposite process, with less deposition of material.

\subsection{Spray angle}

The effect of spray angle ${ }^{29}$ can mainly influence the deposition efficiency and consequently coating thickness. Phase angle influence on the deposition efficiency can be evaluated dividing the spray angle values into three regions: maximum angle deposition efficiency (angle normal to the substrate surface), transient angle range (the deposition efficiency increases from zero at the critical spray angle to $100 \%$ and depends on the particle velocity distribution) and no deposition efficiency angle range (spray angle $<40^{\circ}$ and depends on the material being sprayed). The phase angle also influences the microstructure of the coating and the deformation flow direction of particles in the coating is almost perpendicular to the particle approaching direction.

\subsection{Substrate temperature}

The substrate temperature may also influence the performance of the coating. The increase of substrate temperature will contribute to deposit at lower particle velocity, since the thermal-softening effect can be present during the particle impact the substrate. The deposition of $\mathrm{Cu}$ and $\mathrm{Al}$ on $\mathrm{Al}_{2} \mathrm{O}_{3}$ by $\mathrm{CGS}$ on heated substrates resulted in relatively low compressive stresses and low hardness, high electrical conductivity values, and improvement of the coatings properties ${ }^{30}$.

\subsection{Feedstock powder}

\subsubsection{Main processes for obtaining powders}

\subsubsection{Atomization}

The gas atomization is the cheapest and most suitable process for the manufacturing of the feedstock powder for CGS spraying ${ }^{31-33}$. This technique can easily produce a high amount of feedstock with spherical morphology and regular size between $10 \mu \mathrm{m}$ to $100 \mu \mathrm{m}$. The powders show a micrometer particle size with submicron particles formed during solidification in the gas atomization process ${ }^{31-33}$.

In the atomization process (Figure 9), the metal is melted in a high temperature furnace using air, nitrogen, or helium atmosphere ${ }^{31,33}$. The liquid metal flows through the hole between two small nozzles which work with a high gas pressure, and simultaneously the gas jet disperses the liquid metal to lead the formation of small droplets, which cooling down during their fall in the atomizing tower and become solid particles ${ }^{31,33}$. 


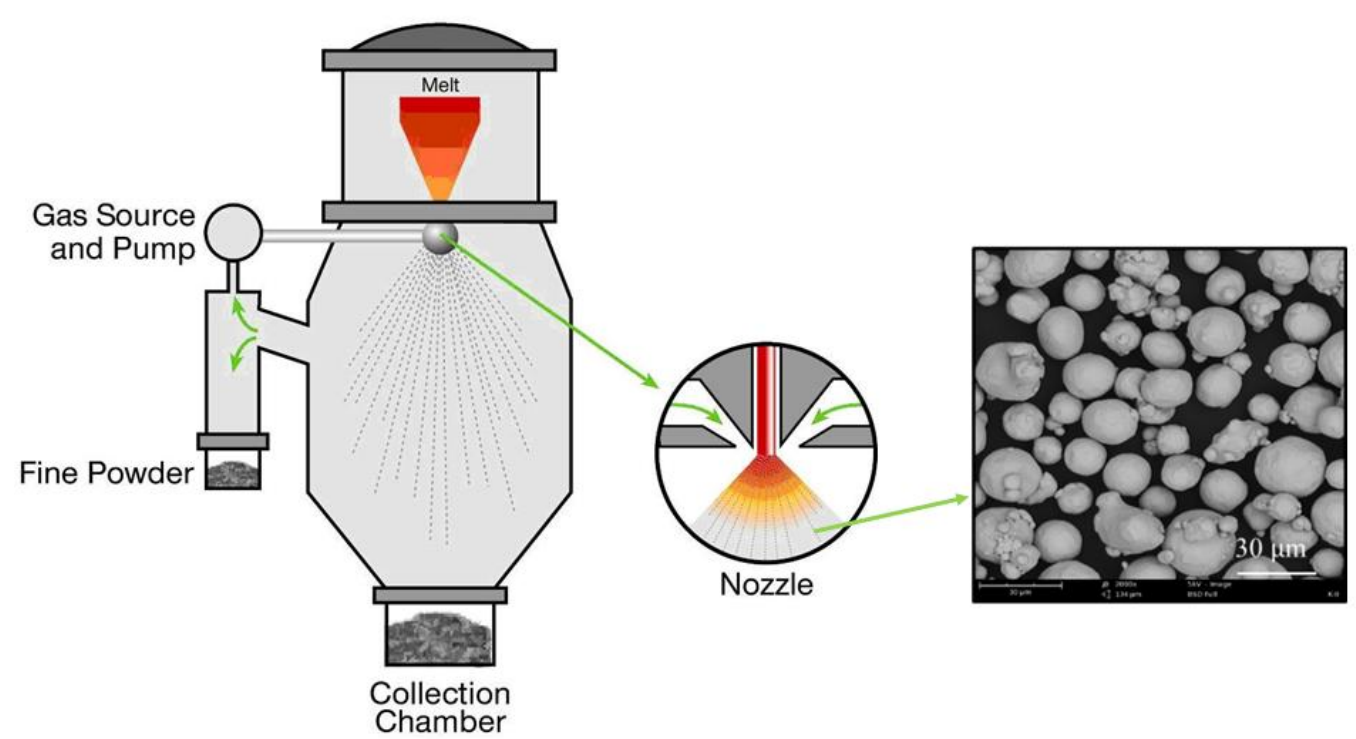

Figure 9. a) Atomization system for powder production and b) Copper powder prepared by gas atomization process using air atmosphere ${ }^{34}$.

\subsubsection{Agglomeration and sintering}

Metallic-ceramic powders, e.g. tungsten carbides (WCs) are produced by the agglomeration and sintering process $^{1,10,35-37}$. Sintering occurs from a solid-state reaction between calcium tungstate $\left(\mathrm{CaWO}_{4}\right)$ and calcium carbides $\left(\mathrm{CaC}_{2}\right)$ at temperatures close to their respective melting points. After the reaction, $\mathrm{WC}$ is obtained in a ratio up to $65 \% \mathrm{wt}$. To produce tungsten carbide and cobalt (WC-Co) the last step is mixing Co in amounts between $12-20 \%$ wt at inert atmosphere, usually pure nitrogen. The prepared powder (Figure $10)$ is porous and has good regularity in size and shape.

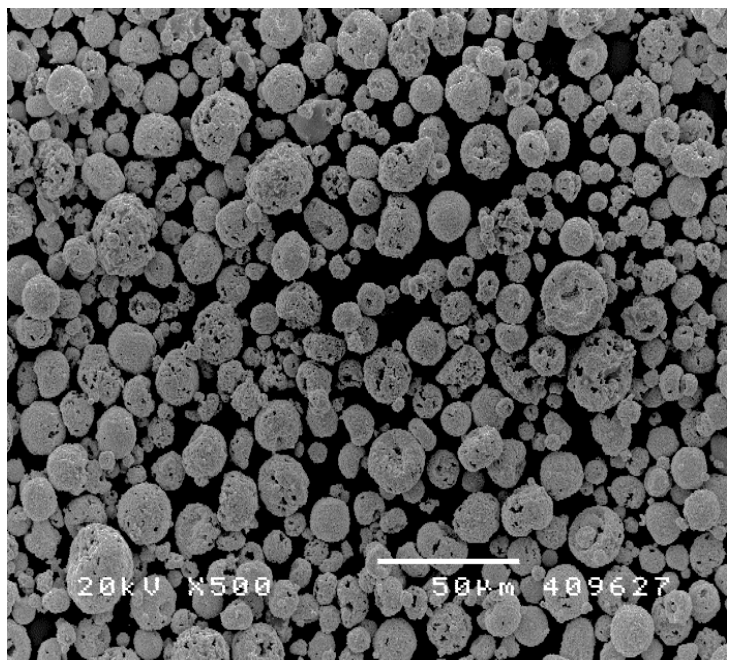

Figure 10. WC-Co powder prepared by agglomeration and sintering.

\subsubsection{Mechanical process}

Composite feedstock powder or obtained from metallic alloys can be prepared by mechanical processes using ball milling system (Figure 11). In this process, zirconia or ceramic balls are placed inside a cylindrical metal chamber with the material to be processed. In the ball milling system at certain velocity the balls press the material on the cylinder walls, the friction increases the temperature and the pressure causes the plastic deformation of the particles ${ }^{31}$. The particle size reduction results from a complicated dynamic interaction of the balls with turbulent slurry during the ball milling process. As seen in Figure 11, particle breakage may occur by the collision of balls in many places. The morphology of these powder depends on many parameters, such as ball size, ball shape, ball filling, slurry loading (with respect to ball amount), powder loading with regard to the amount of total slurry (slurry viscosity), and rotation speed ${ }^{38}$. 


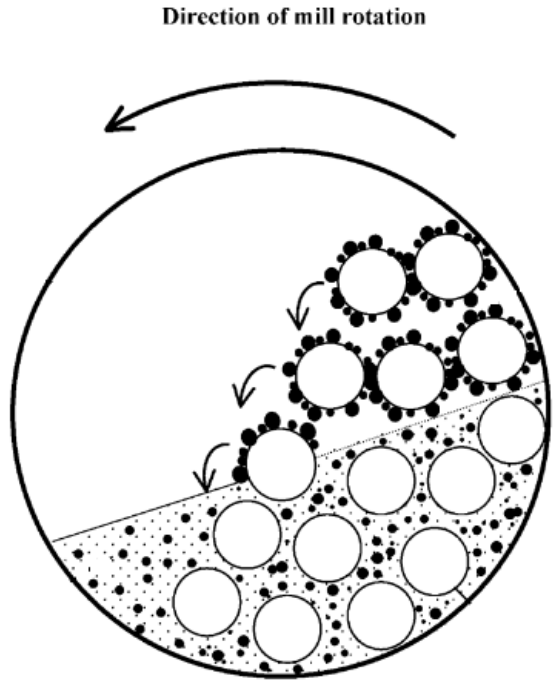

Figure 11. Ball milling system used for feedstock powder producing. Adapted from [39] with permission.

\subsubsection{Influence of composition, structure, and size of the feedstock powder}

Materials used in CGS have the morphology of powder. Before using any kind of material, it is extremely important to know some characteristics such as: chemical composition, crystalline structure (metals) or polymer structure (polymers), size and morphology of the particles, and physical and mechanical properties as well. These characteristics help us to choose which parameters are most suitable for spraying the feedstock powders. The determination of the composition and crystalline structure of the metallic feedstock powders can be performed by X-ray diffraction analysis. In CGS, the plastic deformation of the particle depends on temperature and pressure during the coating building. For metals, it is also dependent on the kind of crystalline structure of the feedstock material ${ }^{12,40}$. Metals with face-centered cubic (FCC) structure deform plastically more easily, because the crystalline structure of these metals is symmetrical, which facilitates the sliding of the crystalline planes, making these materials less resistant to the plastic deformation. Metals as aluminum, copper, silver, and others having a FCC structure are easily deposited by CGS. On the other hand, metals with body-centered cubic (BCC) are more difficult to be plastic deformed and the spraying parameters should be investigated with more caution for their deposition. This is the case of tungsten, tantalum, vanadium, and others.

Metals like $\mathrm{Zn}, \mathrm{Al}$ and $\mathrm{Cu}$ are ideal for CGS deposition due to low mechanical strength and relatively low melting point, requiring low process temperatures and no gas pre-heating to deposit dense coatings. Al deposition is little difficult than the others because of its high heat capacity despite its low melting point and low yield strength. For these metals and their alloys, the thermal properties are not considered, but this property can be important for materials with higher strength, e.g., Fe-, Ni- and Ti-based materials. In these cases, low process temperatures may not be successful in depositing them, since no enough energy is provided, but even thus, deposition of these materials using CS technology has been reported ${ }^{41}$.

For the polymeric materials, thermoplastic polymers are the most used for the coating production by $\mathrm{CGS}^{42}$. These polymers have plastically deformed under different pressure and temperature conditions. In addition, these polymers are easily produced in powder form. Among the most used polymers are polyethylene and polyethylene terephthalate. The analysis of the size and morphology of the powders are performed using laser diffraction (DL) measurements and scanning electron microscopy (SEM), respectively. Laser diffraction measures the particle size distribution by the angular variation in the intensity of diffused light as a laser beam interacts with the particles dispersed in liquid. SEM allows analyzing the morphology which is performed both on free surface and cross section.

The analysis of the morphology and size of the particle is extremely useful due to the strong influence they exert on the critical velocity. The velocity of the particle during the spraying process is inversely proportional to its size. Accordingly, higher velocities are achieved using smaller particle size. However, studies show difficulty in spraying small particles (size $<5 \mu \mathrm{m}$ ), because these undergo agglomeration, which can cause problems such as nozzle clogging ${ }^{1,31,43}$. The particle size for CGS can be between $5-400 \mu \mathrm{m}^{1}$, but the ideal size of particles is much lower, between 1-50 $\mu \mathrm{m}^{21,43}$.

\subsubsection{Influence of powder morphology}

For a particular material both particle size and morphology are very important parameters to determine if the critical velocity will be surpassed. Particles with irregular form are easier accelerated than spherical particles with the same size due to hydrodynamic effects, however irregular and coarse particles have their velocity diminished that can be lower than smaller spherical particles. An experimental study on the influence of the titanium powder composed of agglomerates and deposited on 7075-T6 $\mathrm{Al}$ alloy was developed to understand the formation process of the coating / substrate interface and particle / 
particle boundary within aggolomerate ${ }^{44}$. Transmission electron microscopy examinations of a focused ion beam lift-out prepared sample pointed out to jettingout, the occurrence of oxide layers and grain size refinement as the key aspects. Recrystallization was exhibited for both $\mathrm{Al}$ alloy titanium side at the particlesubstrate interface and $\mathrm{Ti}$ particles in small agglomerates showed grain refinement at particle / particle interface while the original structure was preserved outside those boundaries. The structure within the titanium particles was highly heterogeneous and seems that the irregular particle morphology influenced the stress distribution and a non-uniform contact at the substrate / particle interface.

\subsection{Influence of spray gun and nozzle}

\subsubsection{Spray gun}

Figure 12 shows a scheme of a CGS Gun. The most important parts are the high pressure / heating chamber and the nozzle. The chamber has the function of maintaining the working temperature of the gas and is also the place where the high-pressure system of the gas / particle mixture is formed ${ }^{45}$. Most commercially available spray guns are similar in design to Figure 12.

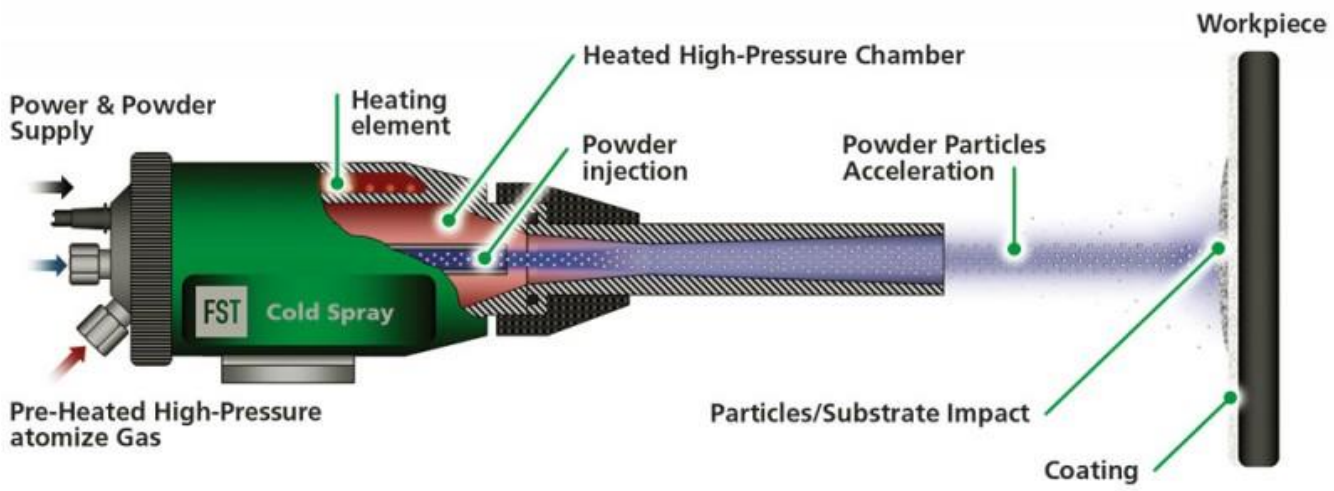

Figure 12. Spray gun for CGS ${ }^{45}$. From https://www.fst.nl/systems/cold-gas-spray/ (accessed October 24, 2017).

\subsubsection{Spray gun nozzle}

In CGS, the particles are accelerated and heated due to their interaction with the high velocity gas flow. The main purpose of the nozzle in this system is to form a particle / gas flow with sufficient thermal and kinetic energy for successful deposition to occur. The nozzle of the spray gun is a piece usually made from tungsten carbide or polymers. The nozzles can be constructed with different geometries; however, three types are the most common: convergent, convergent / divergent conical and convergent / divergent cylindrical (Figure 13).

(a)

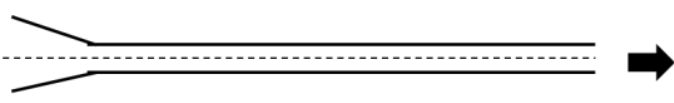

(b)

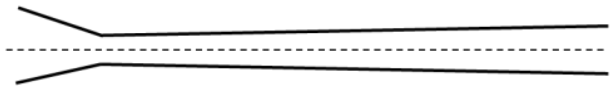

(c)

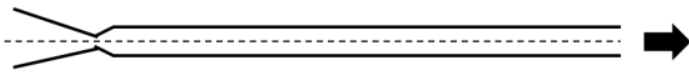

Figure 13. Schematic cross sections of the cold spray nozzles: (a) convergent-barrel nozzle; (b) convergentdivergent nozzle; (c) convergent-divergent-barrel nozzle.
The nozzles may have differences in the gas inlet diameter, throat diameter, gas expansion outlet diameter and divergent and convergent section length, all factors influence the velocity of the particle during spraying $^{1,46}$. Computational simulation studies ${ }^{1,46}$ have shown that the higher the nozzle length, the higher the particle velocity during spraying. The velocity of the particles after the exit of the nozzle is also greater for a convergent / divergent system. This nozzle is also capable of spraying particles with diameter up to $\approx 400$ $\mu \mathrm{m}$, which results in a denser coating.

\subsection{Substrate preparation}

Preparation of the substrate surface is very important when it is desired to produce a coating by CGS. It is mandatory that the substrate be clean and free from chemical residues and oxides prior to coating deposition. Before spraying, the preparation of the substrate is mainly done in two ways: abrading using silicon carbide papers ( $\mathrm{SiC}$ ) which provides a roughness around $0.5 \mu \mathrm{m}$, or blasting, which is the most widely used method, in which $\mathrm{Al}_{2} \mathrm{O}_{3}$ particles are blasted on the substrate surface, what may produce a surface roughness up to $5 \mu \mathrm{m}^{47}$. To prepare the surface by blasting procedure, it is important to define the 
following parameters / conditions: the type of particle used, its size and shape, gas pressure, angle, and time of blasting, as these characteristics can determine how rough the surface may be $\mathrm{be}^{31,48}$.

In general, $\mathrm{Al}_{2} \mathrm{O}_{3}$ particles of granular shape and size of less than $100 \mu \mathrm{m}$ are used. Blasting is done in a short time, with the sample at $90^{\circ}$ angle and using pressures less than 5 bar. CGS equipment having two spray powder compartments may be used to make the blasting process followed by spray coating. This is a great advantage as it prevents exposure of the clean surface to the environment for a long time, preventing the formation of oxides or deposition of dirt on the surface. Studies report that when CGS coatings are deposited on rougher surfaces, the deposition efficiency of the material increases ${ }^{3,31,47,48}$. This happens because the particles deform more severely on a rough surface than on a smooth surface. In addition, these coatings show greater adhesion on blasted substrates $^{3,22,47,48}$.

Another way of surface preparation is laser abrasion which uses a short pulse laser system to rapidly vaporize a surface layer from the substrate. This technique is widely used for surface preparation of biomaterials that will be coated with CGS technique. Surface preparation methods such as chemical cleaning or electropolishing are generally poorly used and there is no literature about studies showing spray coatings on so prepared surfaces. Different materials can be sprayed on a flat surface that constitutes an advantage of CGS technique.

\section{Some relevant corrosion studies of cold spray coatings and corrosion protection}

Corrosion has been defined as the undesirable deterioration of a metal or alloy, or other material, i.e., an interaction of the material with its environment that adversely affects those properties of the material that are to be preserved ${ }^{49}$. An alternative for protecting the substrate from contact with the environment and prevent its corrosion is the use of coatings. The coating has a purpose of covering the metal surface and acting as a barrier preventing that oxygen, water, chloride ions and other aggressive substance reach the substrate and begin its corrosion. The corrosion resistance of CGS coatings depends mainly on the porosity and thickness of the coatings. Coatings with corrosion resistance for long immersion times show porosity values less than $1 \%$ and can be considered as compact $^{35,47}$. They also show an increase in the corrosion resistance by increasing their thickness. It has happened because for a thicker coating the interconnected porosity and paths formation that allow the electrolyte to reach the coating/substrate interface can occur after a long immersion time compared to a thin coating. In addition, to draw a general guideline towards improved corrosion resistance, an understanding of the effects of cold spray parameters and conditions on corrosion behavior is essential. Cold spray provides the possibility of exploring wide range of materials system for corrosion protection. Some of relevant studies about the CGS coatings and their corrosion features are show in Table 2.

Before the CGS process, a thick aluminum-based coating with low porosity could be hardly obtained by conventional methods. Even utilizing spray techniques such as HVOF and Plasma Spray, the deposition of aluminum coatings was difficult because of the high temperatures used during the spray process that causes the melting of the feedstock material and a high oxidation of aluminum. An extensive literature ${ }^{52,53,64-87}$ shows the production of the aluminum CGS coatings and in some of these works ${ }^{47,52,53,56,73,82,83,88}$ also the corrosion resistance was evaluated.

Silva et $a .^{47}$, using SEM images, measuring the open circuit potential $\left(E_{\mathrm{OCP}}\right)$ and working with electrochemical impedance spectroscopy (EIS), have evaluated the corrosion resistance during long immersion times of $\mathrm{Al}$ coatings deposited onto ground low carbon steel (time up to $600 \mathrm{~h}$ ) and grit blasted steel (time up to $2000 \mathrm{~h}$ ). A reinforced aluminum/alumina $\left(10 \% \mathrm{Al}_{2} \mathrm{O}_{3}\right)$ coating was also evaluated (time up to $600 \mathrm{~h})^{47}$. The $\mathrm{Al} /$ grit blasted steel show a thickness of $381 \mu \mathrm{m}$, which was thicker than the $\mathrm{Al} /$ ground steel $(309 \mu \mathrm{m})$ and the reinforced coating $(320 \mu \mathrm{m})$.

For Al-based coatings, the $E_{\mathrm{OCP}}$ measurements during long immersion times showed potential oscillations (Figure 14). At the end of the experiments, all coatings showed a potential value close to -0.87 $\mathrm{V} / \mathrm{Ag}|\mathrm{AgCl}| \mathrm{KCl} 3 \mathrm{~mol} / \mathrm{L}$, which suggests that the electrolyte did not attack the substrate yet, since the potential of the substrate was around -0.75 $\mathrm{V} / \mathrm{Ag}|\mathrm{AgCl}| \mathrm{KCl} 3 \mathrm{~mol} / \mathrm{L}$. 
Table 1. Coatings prepared by CGS for corrosion protection purpose and their features.

\begin{tabular}{|c|c|c|c|c|c|c|c|c|c|}
\hline Coating & Substrate & Corrosion test & Thickness & Porosity & Adhesion & Hardness & RB volume loss & SW volume loss & Ref. \\
\hline $\mathrm{Al}$ & carbon steel & 2000 h (salt spray) & $381 \mu \mathrm{m}$ & $<0.8 \% *$ & $30 \mathrm{MPa}$ & $51 \pm 3 \mathrm{HV}_{100}$ & $1.9 \times 10^{-4} \mathrm{~mm} 3 / \mathrm{Nm}$ & $(9 \pm 2) \times 10^{-4} \mathrm{~mm}^{3} / \mathrm{Nm}$ & [47] \\
\hline $\mathrm{Al}-\mathrm{Al}_{2} \mathrm{O}_{3} / \mathrm{Al}$ & carbon steel & $2000 \mathrm{~h}$ (salt spray) & $320 \mu \mathrm{m}$ & $<0.8 \% *$ & $30 \mathrm{MPa}$ & $65 \pm 5 \mathrm{HV}_{100}$ & $1.7 \times 10^{-4} \mathrm{~mm} 3 / \mathrm{Nm}$ & $(6 \pm 1) \times 10^{-4} \mathrm{~mm}^{3} / \mathrm{Nm}$ & [47] \\
\hline $\mathrm{Zn}-\mathrm{Ni}$ & carbon steel & $1000 \mathrm{~h}\left(E_{\mathrm{OCP}}, \mathrm{EIS}\right)$ & - & - & - & - & - & - & {$[50]$} \\
\hline Ti6Al4V & AA6061 & $4 \mathrm{~h}\left(E_{\mathrm{OCP}}\right)$, polarization curves $3.5 \% \mathrm{NaCl}$ & $2.35 \mathrm{~mm}$ & $2.8 \% *$ & $50.3 \mathrm{MPa}$ & $485 \mathrm{HV}_{500}$ & - & $112 \times 10-5 \mathrm{~mm}^{3} / \mathrm{Nm}$ & [51] \\
\hline CoCrMo & AA6061 & $4 \mathrm{~h}\left(E_{\mathrm{OCP}}\right)$, polarization curves $3.5 \% \mathrm{NaCl}$ & $2.4 \mathrm{~mm}$ & $2.5 \% *$ & $66 \mathrm{MPa}$ & $362 \mathrm{HV}_{500}$ & - & $3.89 \times 10-5 \mathrm{~mm}^{3} / \mathrm{Nm}$ & [51] \\
\hline $\mathrm{Al}$ & AZ31B & $2000 \mathrm{~h}$ (salt fog) & $250 \mu \mathrm{m}$ & - & - & $52 \mathrm{HV}_{100}$ & - & - & {$[52]$} \\
\hline $\mathrm{Al}$ & AZ91D & $\begin{array}{c}E_{\mathrm{OCP}} \text { and EIS (240 h), Cyclic polarization - } \\
150 \mathrm{mV} \text { to }+100 \mathrm{mV} v s . E_{\mathrm{OCP}} \text { at } 1 \mathrm{mV} / \mathrm{s} \\
3.5 \% \mathrm{NaCl}\end{array}$ & - & - & - & - & - & - & [53] \\
\hline Ti6Al4V & Ti6Al4V & $\begin{array}{c}E_{\mathrm{OCP}} \text { and EIS }(25 \mathrm{~h}), \text { polarization curves - } \\
200 \mathrm{mV} \text { to }+250 \text { at } 0.5 \mathrm{mV} / \mathrm{s} 3.5 \% \mathrm{NaCl}\end{array}$ & $9 \mathrm{~mm}$ & $3.5 \pm 0.9^{*}$ & & $\approx 450 \mathrm{HV}_{200}$ & - & $92 \times 10^{-14} \mathrm{~m}^{3} /(\mathrm{Nm})$ & [54] \\
\hline $\mathrm{Zn}$ & mild steel & $72 \mathrm{~h}\left(E_{\mathrm{OCP}}, \mathrm{EIS}\right) 3.5 \% \mathrm{NaCl}$ & $750 \mu \mathrm{m}$ & $0.25 \% *$ & - & $55 \mathrm{HV}_{100}$ & - & - & [55] \\
\hline $\mathrm{Al}$ & Q235 steel & $480 \mathrm{~h}\left(E_{\mathrm{OCP}}, \mathrm{EIS}\right) 3.5 \% \mathrm{NaCl}$ & & - & - & - & - & - & [56] \\
\hline WC-25Co & Carbon steel & $16 \mathrm{~h} E_{\mathrm{OCP}} 3.5 \% \mathrm{NaCl}$ & $263 \mu \mathrm{m}$ & - & $74 \mathrm{MPa}$ & $981 \mathrm{HV}_{100}$ & & & [35] \\
\hline WC-25Co & Al7075-T6 & $16 \mathrm{~h} \mathrm{E}_{\mathrm{OCP}} 3.5 \% \mathrm{NaCl}$ & $211 \mu \mathrm{m}$ & - & - & $848 \mathrm{HV}_{100}$ & $2.87 \times 10^{-5} \mathrm{~mm}^{3} \mathrm{~N} / \mathrm{m}$ & - & [35] \\
\hline WC-12Co & Al7075-T6 & $24 \mathrm{~h} E_{\mathrm{OCP}} 3.5 \% \mathrm{NaCl}$ & $93 \mu \mathrm{m}$ & - & $19 \mathrm{MPa}$ & $1419 \mathrm{HV}_{100}$ & $8.7 \times 10^{-6} \mathrm{~mm}^{3} / \mathrm{N}$ & $0.0038 \mathrm{~mm}^{3}$ & [11] \\
\hline WC-17Co & Al7075-T6 & $24 \mathrm{~h} E_{\mathrm{OCP}} 3.5 \% \mathrm{NaCl}$ & $129 \mu \mathrm{m}$ & - & $26 \mathrm{MPa}$ & $1223 \mathrm{HV}_{100}$ & $1.3 \times 10^{-5} \mathrm{~mm}^{3} / \mathrm{N}$ & $0.0086 \mathrm{~mm}^{3}$ & [11] \\
\hline $\mathrm{Al}-5 \% \mathrm{Mg}$ & ZE41A-T5 Mg & 1000 h (salt spray) & $380 \mu \mathrm{m}$ & $0.5 \%^{\mathrm{a}}$ & $60 \mathrm{MPa}$ & 124 & & & [57] \\
\hline $\mathrm{Ti}$ & Q235A steel & $\begin{array}{c}E_{\mathrm{OCP}} 800 \mathrm{~h} \text {, Cyclic polarization } \\
-150 \mathrm{mV} \text { to }+100 \mathrm{mV} v s . E_{\mathrm{OCP}} \text { at } 1 \mathrm{mV} / \mathrm{s} \\
3.5 \% \mathrm{NaCl}\end{array}$ & $1 \mathrm{~mm}$ & $1.6 \%{ }^{*}$ & - & - & - & - & {$[57]$} \\
\hline Ti-polished & Q235A steel & $\begin{array}{c}\mathrm{E}_{\mathrm{OCP}} 800 \mathrm{~h} \text {, polarization curves } \\
-600 \mathrm{mV} \text { to }+600 \mathrm{mV} \text { vs } \mathrm{E}_{\mathrm{OCP}} \text { at } 10 \\
\mathrm{mV} / \mathrm{min} 3.5 \% \mathrm{NaCl}\end{array}$ & $1 \mathrm{~mm}$ & $1.6 \%{ }^{*}$ & - & - & - & - & {$[58]$} \\
\hline $\mathrm{Ta}$ & low carbon steel & $\begin{array}{c}\text { Tafel curves } 1.5 \text { to }+1 \mathrm{~V} \text { at scan rate of } 1 \\
\mathrm{mV} / \mathrm{s} \text { and EIS } 1 \mathrm{~mol} / \mathrm{L} \mathrm{KOH}\end{array}$ & $800 \mu \mathrm{m}$ & $0.3 \% *$ & - & $350 \mathrm{HV}_{100}$ & - & - & [59] \\
\hline SS 316L & mild steel substrate & polarization curves in $0.1 \mathrm{~N} \mathrm{HNO}_{3}$ & - & $0.8 \% *$ & - & $298 \mathrm{HV}_{100}$ & - & - & [60] \\
\hline $\mathrm{Al}$ & $\mathrm{NdFeB}$ & Tafel curves and EIS $3.5 \% \mathrm{NaCl}$ & $170 \mu \mathrm{m}$ & - & - & - & - & - & [61] \\
\hline $\begin{array}{l}316 \text { L stainless } \\
\text { steel }\end{array}$ & AZ91E & Tafel curves $0.166 \mathrm{mV} \mathrm{s}^{-1}$ & $300 \mu \mathrm{m}$ & $4 \% *$ & - & - & - & - & [62] \\
\hline $\begin{array}{l}20 \mathrm{wt} \% \\
\mathrm{HAP} / \mathrm{Ti}\end{array}$ & $\mathrm{Ti}$ & $\begin{array}{c}-1 \mathrm{~V} \text { to }+5 \mathrm{~V} \text { at } 1 \mathrm{mV} / \mathrm{s} \text { and EIS in Hanks' } \\
\text { solution }\end{array}$ & $200 \mu \mathrm{m}$ & - & - & $130 \mathrm{HV}_{100}$ & - & - & [63] \\
\hline $\begin{array}{l}20 \mathrm{wt} \% \\
\mathrm{HAP} / \mathrm{Ti}\end{array}$ & $\mathrm{Ti}$ & $\begin{array}{c}-1 \mathrm{~V} \text { to }+5 \mathrm{~V} \text { at } 1 \mathrm{mV} / \mathrm{s} \text { and EIS in Hanks' } \\
\text { solution }\end{array}$ & $200 \mu \mathrm{m}$ & - & - & $330 \mathrm{HV}_{100}$ & - & - & [63] \\
\hline
\end{tabular}

* Porosity estimated on the basis of the ASTM E2109-01. ${ }^{\text {a }}$ The method used was not reported. RB - Rubber Wheel test. SW- Sliding wear test. HAP-hydroxyapatite. 


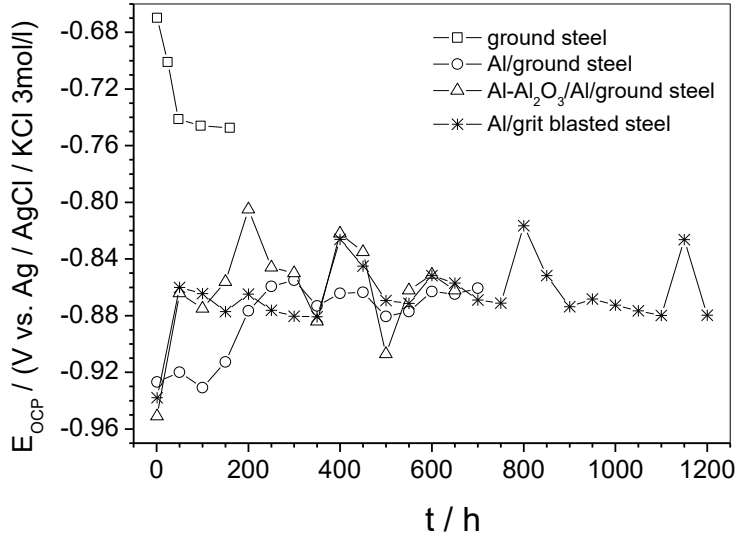

Figure 14. $E_{\mathrm{OCP}}$ versus time measured in aerated and unstirred $3.5 \mathrm{wt} \% \mathrm{NaCl}$ solution for the steel and different coated samples for relatively high immersion times ${ }^{47}$ Reproduce with permission.

The potential oscillations are caused by the formation/repassivation of pits on aluminum surface, probably by a queuing process ${ }^{89}$. For the Al coatings, the pits begin to be formed on the thinner and/or defected aluminum oxide film. For the reinforced coatings, the pits are mainly initiated surrounding the $\mathrm{Al}_{2} \mathrm{O}_{3}$ particles (Figure 15). Corrosion around these particles can be explained, as usual, by the formation of local cells between $\mathrm{Al}_{2} \mathrm{O}_{3}$ (nobler) and the $\mathrm{Al}$ matrix (more active).

The EIS results were analyzed by fitting equivalent electrical circuits $(\mathrm{EEC})^{47} . R_{\mathrm{ox}}$ was assigned to the aluminum oxide itself and aluminum oxidation, $R_{\mathrm{ct}}$ to the charge transfer resistance and $R_{\text {film }}$ was assigned to the resistance of the corrosion products of aluminum which may include oxides with different properties of the native or the $\mathrm{Al}_{2} \mathrm{O}_{3}-\mathrm{Al}$ composite. The resistance values were plotted versus time to compare the different coatings as shown in Figure 16.

For $\mathrm{Al}-\mathrm{Al}_{2} \mathrm{O}_{3} / \mathrm{Al} /$ ground steel coating, the $\left(R_{\mathrm{OX}}+R_{\mathrm{ct}}\right)$ resistance values have varied up and down during all the immersion time, as shown in Figure 16a. The increase of $\left(R_{\mathrm{OX}}+R_{\mathrm{ct}}\right)$ resistance at short immersion times could be related to the oxide formation by the reaction of water with aluminum, increasing the area covered by aluminum oxide ${ }^{47}$. The chloride has begun attacking at the defects of aluminum oxide around the aluminum particles forming local cells, as observed by the SEM images (Figure 15b). For long times, these local cells accelerated the aluminum dissolution leading to a rapid decreasing of the $\left(R_{\mathrm{OX}}+R_{\mathrm{ct}}\right)$ resistance (Figure 16a) . $^{47}$.

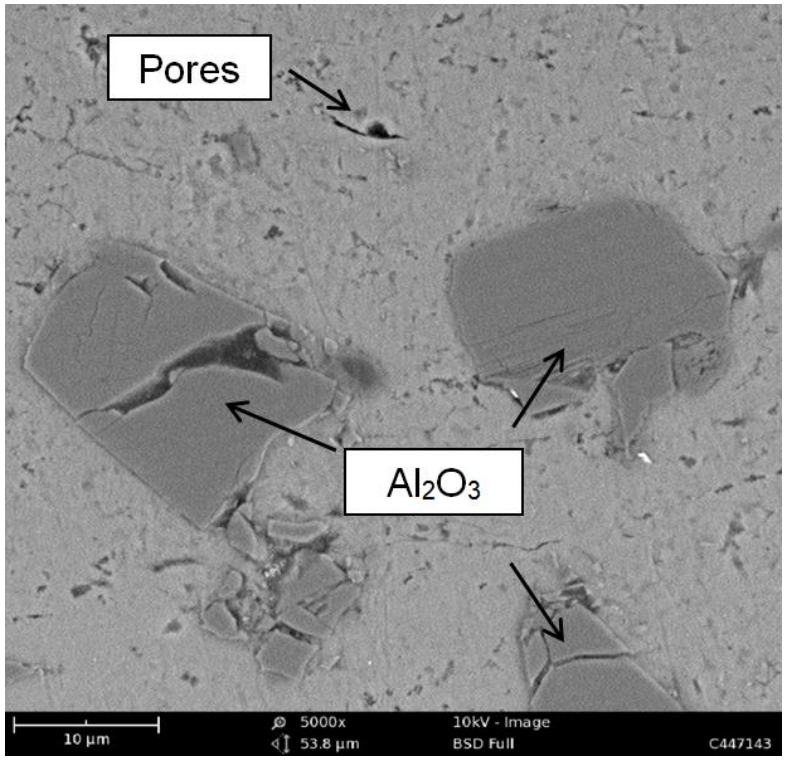

(a)

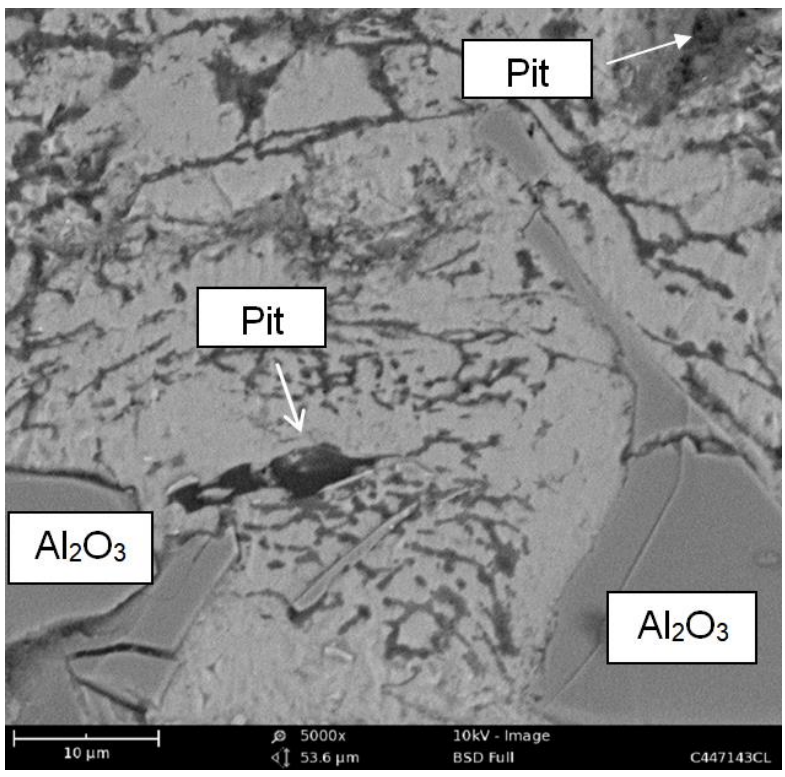

(b)

Figure 15. SEM image of $\mathrm{Al}-\mathrm{Al}_{2} \mathrm{O}_{3} / \mathrm{Al} /$ ground steel coating at high magnification before (a) and after (b) longer immersion times.

$R_{\text {film }}$ values (Figure 16b) also show a sharply decrease to very low values after $500 \mathrm{~h}$ of experiment, probably due to the oxide film dissolution caused by the formation of local cells and preferential attack around the alumina particles, as shown in the SEM image (Figure 15). The EIS analysis and SEM images show that only after $2200 \mathrm{~h}$ the coating show interconnected porosity and some paths that allow the electrolyte to reach the coating/substrate interface. 
Moreover, all the studied Al-based coatings have protected the substrate against corrosion in salt fog tests for a long time such as $3000 \mathrm{~h}^{47}$.

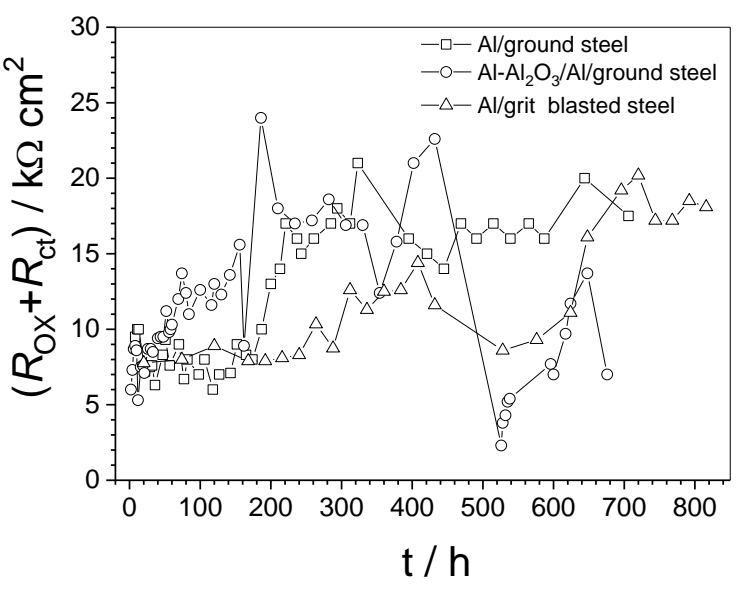

(a)

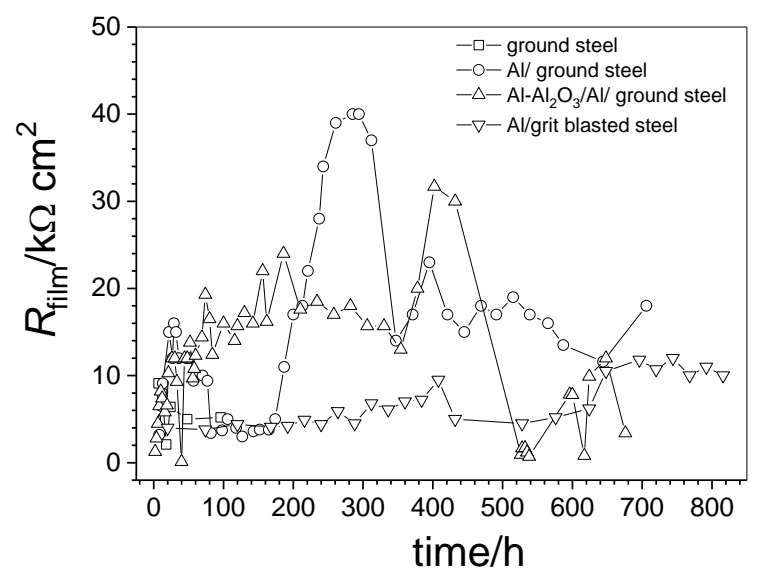

(b)

Figure 16. (a) $\left(R_{\mathrm{OX}}+R_{\mathrm{ct}}\right)$ and (b) $R_{\text {film }}$ for $\mathrm{Al}$ and $\mathrm{Al}-\mathrm{Al}_{2} \mathrm{O}_{3}$ based coatings versus immersion time in $3.5 \% \mathrm{NaCl}$ solution at $25{ }^{\circ} \mathrm{C}^{47}$. Reproduced with permission.

For the Al coatings, the highest initial values $\left(R_{\mathrm{OX}}+R_{\mathrm{ct}}\right)$ were associated with the presence of the natural oxide layer that was formed on the as-prepared surface of the samples. This oxide was attacked, at some defects, by the electrolyte exposing the more active Al coated areas, and, consequently, the resistance has decreased. But, as the time went by, the product of the hydrolysis of aluminum ions might accumulate on the active regions, leading to an increase of the $\left(R_{\mathrm{OX}}+R_{\mathrm{ct}}\right)$ values. In resume, for immersion times $(<200 \mathrm{~h})$, the $\mathrm{Al}-\mathrm{Al}_{2} \mathrm{O}_{3} / \mathrm{Al}$ composite coating showed higher corrosion resistance, probably due to the lower active area of $\mathrm{Al}$, but for immersion times higher than $200 \mathrm{~h}$ a lower corrosion performance was observed due to the severe corrosion of $\mathrm{Al}$ matrix surrounding the alumina particles.

The feedstock powders size and composition also exert influence in the corrosion resistance of CGS coatings and, as previously described, the particle size for CGS particles can be between 5-400 $\mu \mathrm{m}^{1,42,43}$, but the ideal size is below $50 \mu \mathrm{m}^{1,42,44}$. The fine powders, with narrow size distribution and containing low oxygen content are usually more suitable and desirable ${ }^{90}$. Also, the plastic deformation can occur more easily depending on the crystalline structure $^{1,40,52,90}$. All these effects on the coating formation are described in literature ${ }^{1,42}$ and some studies show that they have high influence in the corrosion protection performance ${ }^{62}$. The $316 \mathrm{~L}$ stainless steel with different particle size was deposited under the same spray conditions onto AZ91 alloy and the corrosion resistance evaluated ${ }^{62}$. The coatings prepared with small and large particles showed the same thickness value. However, the porosity was $4 \%$ for large particles powder and less than $1 \%$ for the powder with small particle size. The electrochemical results showed that the corrosion rate decreases by reducing the powder size due to the less porous structure of the coating with smaller particles. The improved quality of interparticle bonding, in this case, also played an important role to reduce the effect of localized corrosive attack.

Different carbide feedstock powders, WC-12Co and WC-25Co, were sprayed by CGS onto Al 7075-T6 alloy and the microstructure and corrosion resistance were evaluated in $\mathrm{NaCl} 3.5 \%$ medium. The cross section images of coatings showed a dense structure with low porosity. The coating thickness was $65 \mu \mathrm{m}$ for WC-12Co and $118 \mu \mathrm{m}$ for WC-25Co. SEM images and electrochemical results after $\sim 700 \mathrm{~h}$ of immersion in $3.5 \% \mathrm{NaCl}$ solution showed that WC-25Co offers higher protection against corrosion of the substrate than WC-12Co. WC-12Co and WC-25Co coatings withstood, respectively, 1000 and $3000 \mathrm{~h}$ of salt fog spray test $^{91}$.

The influence of the oxygen content in the deposition efficiency and corrosion resistance of copper coatings deposited onto low carbon steel using CGS technique was also investigated ${ }^{92}$. The electrochemical results showed that the electrolyte reaches the substrate after $\sim 200 \mathrm{~h}$ of immersion in $3.5 \% \mathrm{NaCl}$ solution for the coatings obtained from the oxidized powders. The coatings obtained from annealed powders showed thickness greater than 500 $\mu \mathrm{m}$ and the electrolyte did not reach the 
substrate/coating interface even after $700 \mathrm{~h}$ of immersion. In addition, they showed high corrosion resistance in salt fog test without any corrosion at the coating / substrate interface for testing time of 2000 $\mathrm{h}^{92}$.

As previously reported, cold-sprayed coatings can be extremely dense and show a very low porosity under suitable spraying conditions, in which the particles experience intense plastic deformation ${ }^{93}$. However, under some spraying conditions and, depending on the starting material, the temperature of particles during the deposition process generates some residual tensile stresses due to thermal effects ${ }^{94,95}$. Moreover, the severe impact deformation generates some residual compressive stresses due to the kinetic effects ${ }^{26-28,31}$. The existence of residual stresses in the cold-sprayed coatings can decrease the mechanical, thermal, electrical and corrosion resistance properties. An alternative to improve the performance of these coatings is the use of heat treatment as previously reported $^{63,66,75,78,81,84,93,96,97}$. Heat treatment can effectively change the microstructure of cold-sprayed $\mathrm{Cu}^{82,86,87,94,98,99}, \mathrm{Al}^{75,78,93}$, stainless steel coatings ${ }^{60,100}$ and Inconel $718^{101}$. Moreover, the mechanical properties (tensile strength, elongation) and corrosion resistance of cold-sprayed coatings may also be improved by applying heat treatments ${ }^{60,94}$.

The evolution of cold-sprayed coatings microstructure during heat treatment was discussed in literature $^{93}$. Two typical cold sprayed coatings, i.e., dense, and porous are shown in Figure 17.

At lower heat-treating temperature, some diffusion between particles will happen as shown in Figure 17b. For the porous coating, the interface between particles will become obscure for the dense coating and only the compactly connected interfaces will disappear ${ }^{93}$. This improves the bond between the particles interface. However, dense coatings will become more compact and stronger, but with low ductility ${ }^{93}$. Further increasing in the heat treatment temperature, diffusion at the particle interfaces became more intense and the interfaces completely disappear (Figure 17c). If the heat treatment temperature is too high, the grain will grow as shown in Figure $17 \mathrm{~d}$. In summary, heat treatment improves the bonding quality and diminishes interparticle boundaries, which are preferential sites for corrosion. Moreover, the heat treatment decreases the coating porosity and increases the coating barrier effect $^{51,55,93}$ (a)

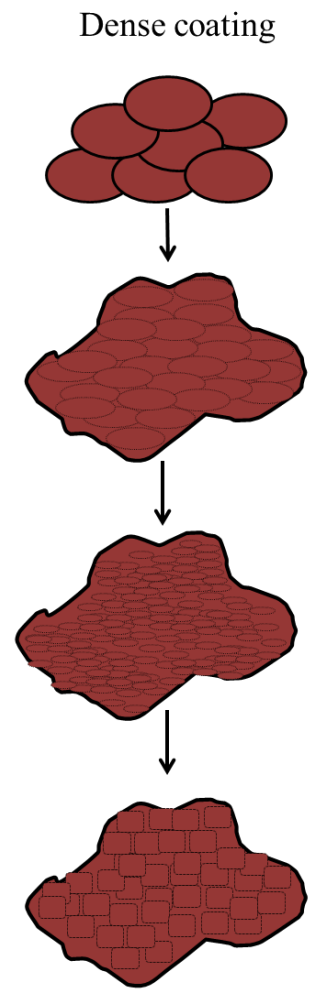

Porous coating

(b)

(c)

(d)

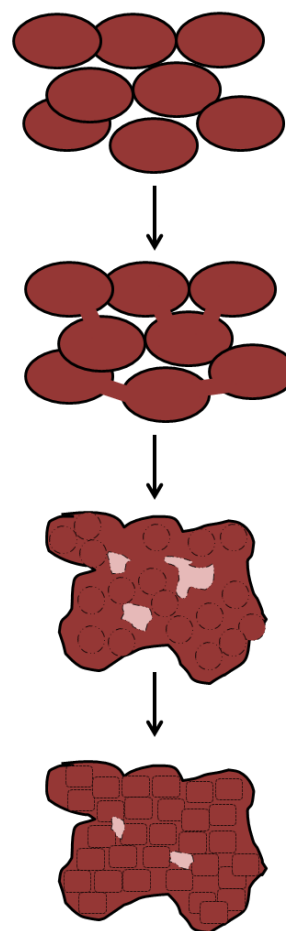

Figure 17. Schematic representation of the evolution of cold spray coatings during heat treatment.

As-prepared and heat-treated tantalum sprayed CGS coatings onto low carbon steel were compared by means of corrosion tests with the bulk material ${ }^{59}$. The coatings were thermally treated at 500, 750, 1000, 1250 , and $1500{ }^{\circ} \mathrm{C}$ in a vacuum furnace for $2 \mathrm{~h}$. The microstructure analyses show an exponential decrease in the porosity from $0.3 \%$ (as-prepared) to $0.05 \%$ $\left(1500{ }^{\circ} \mathrm{C}\right)$. The decrease in porosity has directly influenced the corrosion resistance of coatings. Cyclic polarization test in $1 \mathrm{~mol} \mathrm{~L}^{-1} \mathrm{NaOH}$ solution showed that the changes in current density and corrosion potential are compatible with an enhancing of the corrosion resistance of the coatings because of the heat treatment. The corrosion currents of as-deposited coatings and those heat-treated at $1500{ }^{\circ} \mathrm{C}$ were found to be 7.1 and $0.7 \mu \mathrm{A} / \mathrm{cm}^{2}$, respectively. This indicates substantially superior performance of heat-treated coatings, approaching that of the bulk, which was found to have a corrosion current density of 0.52 $\mu \mathrm{A} / \mathrm{cm}^{2}{ }^{59}$. For all the heat-treated specimens, during reverse polarization, the current density showed a lower value than during the forward scan, which is an indication of effective repassivation. It is evident from these results that closure of pores and cracks, with reduction in grain boundaries, due to the heat treatment, is responsible for the increase of corrosion resistance $^{59}$. 
Sundararajan et $a l .^{60}$ demonstrated that the corrosion resistance of cold-sprayed SS 316L coatings increases as a function of the temperature of heat treatment for different exposure times in $0.1 \mathrm{~mol} \mathrm{~L}^{-1}$ $\mathrm{HNO}_{3}$. As-prepared condition showed a microstructure characterized by weakly / unbounded intersplat boundaries and high porosity. On the other hand, the heat-treated coatings showed an improved intersplat bonding and porosity decrease. Similar results were found for heat-treated cold-sprayed zinc coatings ${ }^{55}$, SS 304 coatings $^{100}$ and titanium coatings ${ }^{93}$.

EIS measurements of the zinc coatings ${ }^{55}$ during 80 $\mathrm{h}$ of immersion and the fitting of the data were performed using EEC to evaluate the corrosion resistance of as-deposited and heat-treated $\mathrm{Zn}$ coatings in a vacuum oven at $150{ }^{\circ} \mathrm{C}$ for $1 \mathrm{~h}$. The first time constant $C_{\mathrm{dl}} / R_{\mathrm{ct}}$ was assigned to the corrosion process of $\mathrm{Zn}$ coating at the electrolyte/coating interface represented by a charge transfer resistance $\left(R_{\mathrm{ct}}\right)$ in parallel with the double layer capacitance $\left(C_{\mathrm{dl}}\right)$. A second time constant $C_{\text {corr }} / R_{\text {corr }}$ was assigned to the process that occurs at the electrolyte/pore inner surface interface, subsequently to the penetration of the electrolyte into the numerous pores present in the coating.

For as-deposited sample, the $R_{\text {corr }}$ values increased up to $24 \mathrm{~h}$ of immersion. The increase of $R_{\text {corr }}$ value is probably the result of the formation and deposition of corrosion products which interfere in the corrosion process within the pores ${ }^{55}$. On the other hand, for the heat-treated coating, the $R_{\text {corr }}$ value reaches a maximum only at $72 \mathrm{~h}$. This indicates that the corrosion products start interfering with the corrosion process at the pores walls at a much later stage in the case of heat-treated condition $^{55}$. The above observation is consistent with the fact that pores and intersplat cracks are considerably lower in the heat-treated coating ${ }^{55}$. The $R_{\mathrm{ct}}$ values for the $\mathrm{Zn}$ coatings in heat-treated condition are higher than that of the as-deposited $\mathrm{Zn}$ during all immersion times. However, $R_{\mathrm{ct}}$ of the heat-treated coating decreases continuously with increasing exposure duration, indicating a general degradation of the corrosion resistance with increasing exposure. The $R_{\text {ct }}$ results show that for long immersion times, the heat treatment may not improve the corrosion resistance of the CGS coating. Detailed studies analyzing the coatings during immersion times up to $500 \mathrm{~h}$ and evaluating other types of coatings and heat treatment conditions should be performed. It can help to elucidate if the heat treatment influences or not the corrosion resistance of the CGS coatings mainly at long immersion times.

Although the use of the heat treatment helps to improve the corrosion resistance of the coatings, it is necessary to observe if the working temperature used during the heat treatment is suitable. High temperatures may oxidize the coatings and increase their oxide content mainly between splats and on the surface. This condition can also provoke the coating degradation and the formation of new crystalline phases or amorphous material. In some cases, the use of high temperatures may not be sufficient to close large pores or microstructure defects. It can occur mainly in the case of less ductile materials. In these cases, it is better to make an optimization of the spraying parameters or sealing the coatings.

The CGS metallic coatings generally show an acceptable corrosion resistance during long immersion times and under corrosive environments. However, they show a wear resistance less than the bulk material. The use of ceramic particles to make composite coatings improves the mechanical resistance of these coatings ${ }^{47,73,102,103}$. In addition, the CGS technique can produce coatings with high wear resistance using feedstock powders like WC-Co ${ }^{11,35,37,104}$, $\mathrm{WC}+\mathrm{AISI} 316^{105}, \mathrm{Cu}-\mathrm{Al}_{2} \mathrm{O}_{3}{ }^{106,107}$

In preparing this review, we have realized that the comparison of the corrosion behavior of the different coatings deposited by CGS technique is difficult mainly due to lack systematic and long-term electrochemical studies. In many cases, fundamental information such as coating thickness, adhesion values are missing, or the spraying conditions are not clearly informed.

\section{Applications of CGS technology}

As previously described, the first applications of the CGS technique were done in the last decade of last century $^{1}$. In industry, the CGS process improves the performance and functionality of a lot of commercial products increasing their commercial values. This technique also allowed in situ repairing of many materials and industrial parts, increasing the lifetime, and decreasing the parts replacement. CGS offers the possibility to produce more efficient coatings and almost without environmental impact or toxic waste production. Table 2 shows the main applications of coatings produced by CGS in the most varied fields of industry ${ }^{5,108}$. 
Table 2. Applications of the CGS coatings.

\begin{tabular}{|c|c|c|}
\hline Coating & Application & Author \\
\hline \multicolumn{3}{|l|}{ I Metals } \\
\hline $\mathrm{Cu}$ and alloys & $\begin{array}{l}\text { Corrosion protection, electrical and thermal conduction, antimicrobial } \\
\text { activity, repairs, and maintenance }\end{array}$ & {$[109]$} \\
\hline $\mathrm{Al}$ and alloys & Corrosion protection, aircraft parts maintenance & [110] \\
\hline $\mathrm{Zn}$ and alloys & Protection against corrosion, repairs, and maintenance & {$[55]$} \\
\hline Stainless steel & Biomaterials, parts maintenance & {$[62]$} \\
\hline Ti and alloys & Biomaterials, parts maintenance & {$[28,63,111]$} \\
\hline $\mathrm{Ni}$ and alloys & Corrosion protection, parts maintenance & {$[112]$} \\
\hline $\mathrm{Ta}$ & Refractory materials & [113] \\
\hline $\mathrm{Al}-5 \mathrm{Fe}-\mathrm{V}-\mathrm{Si}$ & Internal combustion engines & [5] \\
\hline $\begin{array}{c}\mathrm{Fe}_{72 \cdot 8} \mathrm{Si}_{11 \cdot 5} \\
\mathrm{Cr}_{2.2} \mathrm{~B}_{10.7} \mathrm{C}_{2.9}\end{array}$ & Metallic glass, electronic system & {$[11,114]$} \\
\hline \multicolumn{3}{|c|}{ II Metal matrix composites } \\
\hline $\begin{array}{c}\mathrm{Ti} / \mathrm{Al} \\
\mathrm{TiAl}_{3}-\mathrm{Al}\end{array}$ & Corrosion protection in high temperature systems & {$[1]$} \\
\hline $\mathrm{SiCp} / \mathrm{Al} 5056$ & Corrosion protection & [115] \\
\hline Co+Ni alloys & Nuclear power generation systems, tools & [116] \\
\hline $\mathrm{Nd}_{2} \mathrm{Fe}_{14} \mathrm{~B}+\mathrm{Al}$ & Electronic components, sensors, and actuators & \\
\hline $\mathrm{Al} \mathrm{Al+Mg17Al12}$ & Corrosion protection & [81] \\
\hline WC+AISI316 & Corrosion protection & $\begin{array}{l}{[100,111,105,} \\
117]\end{array}$ \\
\hline $\mathrm{Al} \mathrm{Al}+\mathrm{Al}_{2} \mathrm{O}_{3}$ & Corrosion protection and wear resistance & [47] \\
\hline $\mathrm{Al}+\mathrm{SiC}, \mathrm{Al}+\mathrm{Al}_{2} \mathrm{O}_{3}$ & Electronics components & [47] \\
\hline $\mathrm{Cu}-\mathrm{Al}_{2} \mathrm{O}_{3}$ & Corrosion protection and wear resistance & {$[95,96,106,107]$} \\
\hline $\begin{array}{l}\text { WC-Co, WC- } \\
10 \mathrm{Co}-4 \mathrm{Cr}\end{array}$ & Corrosion protection and wear resistance & {$[25,27,35,37]$} \\
\hline $\begin{array}{c}\mathrm{Cr}_{3} \mathrm{C}_{2}-\mathrm{NiCr} \mathrm{Cr}_{3} \mathrm{C}_{2-} \\
\mathrm{Ni}\end{array}$ & Corrosion protection and wear resistance & [117] \\
\hline $\mathrm{Cu} / \mathrm{Cu}_{2} \mathrm{O}$ & Antifouling & {$[119,120]$} \\
\hline $\mathrm{B}_{4} \mathrm{C} / \mathrm{Ni}$ & Corrosion protection and wear resistance & [121] \\
\hline Ti/ hydroxyapatite & Biomaterials & {$[111,122]$} \\
\hline $\begin{array}{l}\text { Carbon Nanotubes- } \\
\mathrm{Cu}\end{array}$ & Heatsinks in electronic systems & [123] \\
\hline \multicolumn{3}{|c|}{ III Ceramics } \\
\hline $\mathrm{SiC}$ & Corrosion resistance at high temperatures & {$[71,124,125]$} \\
\hline $\mathrm{WO}_{3}$ & Photoelectrodes production & \\
\hline $\mathrm{TiO}_{2}$ & Photocatalysts & [42] \\
\hline $\mathrm{Al}_{2} \mathrm{O}_{3}$ & Wear resistance & $\begin{array}{l}{[61,73,98,110,} \\
115,126]\end{array}$ \\
\hline $\mathrm{TiN}$ & Corrosion protection and wear resistance & [5] \\
\hline \multicolumn{3}{|c|}{ IV Polymers } \\
\hline $\begin{array}{l}\text { Polyamides, } \\
\text { Polyethylene }\end{array}$ & Corrosion protection & [127] \\
\hline \multicolumn{3}{|c|}{ V Nanocrystalline } \\
\hline MCrAlY & Thermal barriers and gas turbines & [128] \\
\hline $\mathrm{Fe} / \mathrm{Al}$ & Corrosion protection in high temperature systems & [129] \\
\hline $\mathrm{CuNiFe}$ & Inert anodes for $\mathrm{Al}$ production/deposition & {$[5]$} \\
\hline
\end{tabular}


The aluminum-based coatings, obtained by CGS, have several applications; due to that, before the onset of CGS, it was very difficult to obtain thick coatings, for instance, based on aluminum with low oxidation. Aluminum-based coatings are the most investigated, mainly in the aeronautical industry in which the CGS technique is also used for parts repairing ${ }^{1}$. Aluminum has also been used to produce conductive coatings on ceramic substrates ${ }^{15}$. The metallization of insulating materials for electronic applications has become a very promising process for the application of the CGS technique, mainly for obtaining ceramic piezoelectric materials that convert mechanical energy into electrical energy or vice versa. Metal electrodes are deposited on the face of piezoceramic sensors at opposite positions each other, allowing the formation of a uniform electric field. The powder spraying to form the coatings does not alter the properties of the substrate, and the thickness of the electrodes is greater than those obtained by sputtering.

Copper-based coatings obtained by CGS have also a potential application in corrosion protection in the electronic industry, in heat exchangers and in conductive systems ${ }^{1,6,7,119}$. The low porosity and low oxide content of these coatings allow greater thermal and electrical conductivity as well as greater resistance to corrosion.

WC-Co-based coatings have large application as protective coatings against mechanical wear and corrosion $^{11,35,36,130,131}$. The hardness of the WC particles confers wear resistance while the metal matrix offers toughness. When sprayed by HVOF, these coatings undergo decomposition to form $\mathrm{W}_{2} \mathrm{C}, \mathrm{W}, \mathrm{Co}_{6} \mathrm{~W}_{6} \mathrm{C}$ and $\mathrm{Co}_{3} \mathrm{~W}_{3} \mathrm{C}$ phases, which makes the coating fragile and with low mechanical strength. On the other hand, WCCo coatings sprayed by CGS do not undergo thermal decomposition and present only the $\mathrm{WC}$ and Co phases, being quite homogeneous and more resistant to wear. One of the applications of these coatings is in turbine rotors used in hydropower plants ${ }^{7}$. These turbines suffer wear due to the erosion process. Water at high pressures plus solid particles collide to the surface of the turbine and remove metallic material. This wear creates a loss of working efficiency and higher working efficiency maintenance costs. Using the WC-Co coatings, the service life of these turbines may be higher due to the wear resistance offered by the coating ${ }^{1}$.

The CGS coatings show corrosion and wear resistance but the technique can produce functionality surfaces as well, for example, photocatalytic ${ }^{42}$ and coatings with antifouling activity ${ }^{119,120}$. The photocatalytic activity and the microstructure of ECTFE polymer composite coatings and $\mathrm{C}-\mathrm{TiO}_{2}$ nanoparticles deposited onto an epoxy resin by low pressure cold gas spraying (LPCGS) was investigated by Robotti et. $a$ l. $^{42}$. To produce the novel coatings, C$\mathrm{TiO}_{2}$ was mixed with an ECTFE polymer, by means of a low energy ball milling (LEBM) process. The LEBM system permits the mechanical anchoring of small $\mathrm{TiO}_{2}$ aggregates around the large ductile polymeric particles. A well-bonded coating with good mechanical coupling and thickness $\approx 400 \mu \mathrm{m}$ was formed onto the substrate. Photocatalytic tests showed that the CGS polymer-TiO coatings actively photodegraded $\mathrm{NO}$ and the byproduct, $\mathrm{NO}_{2}$. Compared to commercial paint, these asprepared coatings enhanced photocatalytic performance.

CGS technology is also able to make the metallization process. It consists in the spraying of a feedstock material onto surfaces with low thermal or electric conductive to improve it is characteristics or bring some functionality to the surface ${ }^{119,120}$. Highdensity polyethylene (HDPE) used in boats parts was metalized by CGS process and has shown excellent antifouling properties. The antifouling activity of HDPE with area of $1 \mathrm{~m}^{2}$ metalized by copper powder using CGS technology and the HDPE covered by conventional antifouling paint was compared ${ }^{119}$. The painted polymer showed $63 \%$ of the total area covered by organic material after 250 days on the other hand only $3 \%$ of the total area was covered for the metalized polymer.

Recently, CGS has been used, combined or not, with other techniques to perform non-thermal freeform fabrication and would be a perspective additive manufacturing technology ${ }^{8}$. When compared to other additive manufacturing methods, CS technology involves neither high-temperature processing as selective laser melting and direct metal deposition nor ecologically unfriendly chemicals as electroplating. The ability of CGS works with multi-materials open a window for new developments as using micronozzles (< $1 \mathrm{~mm}$ diameter with spray spot $<1 \mathrm{~mm}$ ) with optimization of spraying strategies to produce freeform 3D objects.

\section{Concluding Remarks}

Thick coatings with low porosity, without cracks and with low content of oxides may be produced by the cold gas spray (CGS) technique due to the high kinetic energy and low thermal energy used for the coating deposition. 
CGS coatings prepared using optimized conditions may present very high adhesion, very low porosity, excellent mechanical properties, corrosion resistance immersed into an aggressive medium for more than $2000 \mathrm{~h}$, and protection to the substrate against corrosion in salt fog tests for $3000 \mathrm{~h}$. Thus, optimizing all spraying parameters is mandatory to have success in preparing coatings with high corrosion resistance and high mechanical properties performance.

A global characterization of the coatings including chemical, physical, microstructural, mechanical and evaluation of corrosion resistance is essential to give a feedback for improving the performance of coatings which may be applied for multipurpose.

The CGS is not only a promising technology to help industry to solve many local concerns in the present and future, but is a reality in protecting many materials against corrosion and wear, extending their service life and cost-effective by avoiding substitution of many parts in the industrial parks and of industrial products. CGS is also a promising technology to functionalize surfaces for different applications in protection of materials against biocorrosion, antifouling, and energy production, additive manufacturing among other applications.

\section{Acknowledgments}

The authors would like to thank the $\mathrm{CNPq}-$ Conselho Nacional de Pesquisa (Procs. 153177/2014-4 and 201325/2014-4) for the financial support and scholarships.

\section{References}

[1] Champagne V. K. The cold spray materials deposition process Fundamentals and applications, 2007.

https://doi.org/10.1533/9781845693787.frontmatter.

[2] Grigoriev, S., Okunkova, A., Sova, A., Bertrand, P., Smurov, I. Cold spraying: From process fundamentals towards advanced applications, Surf. Coatings Technol. $268 \quad$ (2014) 77-84. https://doi.org/10.1016/j.surfcoat.2014.09.060.

[3] Klassen, T., Gärtner, F., Schmidt, T., Kliemann, J. O., Onizawa, K. Donner, K. R., Gutzmann, H., Binder, K., Kreye, H. Basic principles and application potentials of cold gas spraying, Materwiss. Werksttech. 41 (2010) 575-584. https://doi.org/10.1002/mawe.201000645.

[4] Singh H., Sidhu T. S., Kalsi, S. B. S., Karthikeyan, J. Development of cold spray from innovation to emerging future coating technology, J. Brazilian Soc. Mech. Sci. Eng. 35 (2013) 231-245. https://doi.org/10.1007/s40430-013-0030-1.

[5] Moridi, A., Hassani-Gangaraj, S. M., Guagliano, M., Dao, M. Cold spray coating: review of material systems and future perspectives, Surf. Eng. 30 (2014) 369-395. https://doi.org/10.1179/1743294414Y.0000000270.

[6] Siao, A., Ang, M., Sanpo, N., Sesso, M. L., Kim, S.Y., Berndt, C.C. Thermal Spray Maps: Material Genomics of Processing Technologies, J. Therm. Spray Technol. $22 \quad$ (2013) 1170-1183 https://doi.org/10.1007/s11666-013-9970-3.

[7] Raoelison, R. N., Verdy, Ch., Liao, H. Cold gas dynamic spray additive manufacturing today: Deposit possibilities, technological solutions and viable applications, Mater. Des. 133 (2017) 266-287. https://doi.org/10.1016/J.MATDES.2017.07.067.

[8] Sova, A., Grigoriev, S., Okunkova, A., Smurov, I. Potential of cold gas dynamic spray as additive manufacturing technology, Int. J. Adv. Manuf. Technol. 69 (2013) 2269-2278. https://doi.org/10.1007/s00170013-5166-8

[9] Grujicic, M., Saylor, J. R., Beasley, D. E., DeRosset, W. S., Helfritch, D. Computational analysis of the interfacial bonding between feed-powder particles and the substrate in the cold-gas dynamic-spray process, Appl. Surf. Sci. 219 (2003) 211-227. https://doi.org/10.1016/S0169-4332(03)00643-3.

[10] Grujicic, M.; Sellappan, V.; Mears, L.; Seyr, N.; Obieglo, A.; Erdmann, M.; Holzleitner, J. Selection of the spraying technologies for over-coating of metalstampings with thermo-plastics for use in directadhesion polymer metal hybrid load-bearing components.

https://pdfs.semanticscholar.org/c959/71e51e2d9720135 849cd961766a93369ff41.pdf (accessed November 23, 2017).

[11] Couto, M., Dosta, S., Torrell, M., Fernández, J., Guilemany, J. M. Cold spray deposition of WC-17 and $12 \mathrm{Co}$ cermets onto aluminum, Surf. Coatings Technol. 235 (2013) 54-61. https://doi.org/10.1016/j.surfcoat.2013.07.011.

[12] Bala, N., Singh, H., Karthikeyan, J., Prakash, S. Cold spray coating process for corrosion protection: a review, Surf. Eng. 30 (2014) 414-421. https://doi.org/10.1179/1743294413Y.0000000148.

[13] Pawlowski, L. The science and engineering of thermal spray coatings, John Wiley \& Sons, Chichester, 2nd ed., 2008. 
[14] Henao, J., Concustell, A., Cano, I. G., Dosta, S., Cinca, N., Guilemany, J. M., Suhonen, T., Novel Albased metallic glass coatings by Cold Gas Spray, Mater. $\begin{array}{llll}\text { and } & \text { Des. } & 94 & \text { (2016) }\end{array}$ https://doi.org/10.1016/j.matdes.2016.01.040.

[15] Drehmann, R., Grund, T., Lampke, T., Wielage, B., Manygoats, K., Schucknecht, T., Rafaja, D. Splat formation and adhesion mechanisms of cold gassprayed al coatings on $\mathrm{Al} 2 \mathrm{O} 3$ substrates, J. Therm. Spray Technol. 23 (2014) 68-75. https://doi.org/10.1007/s11666-013-9966-z.

[16] Hassani-Gangaraj, M., Veysse, D., Nelson, K. A., Schuh, C. A. In-situ observations of single microparticle impact bonding, Scripta Mater., 145, (2018), 913. https://doi.org/ 10.1016/j.scriptamat.2017.09.042.

[17] Schmidt, T., Gärtner, F., Assadi, H., Kreye, H., Development of a generalized parameter window for cold spray deposition, Acta Mater. 54 (2006) 729-742. https://doi.org/10.1016/j.actamat.2005.10.005.

[18] Assadi, H., Gärtner, F., Stoltenhoff, T., Kreye H. Bonding mechanism in cold gas spraying, Acta Mater. 51 (2003) 4379-4394. https://doi.org/10.1016/S13596454(03)00274-X.

[19] Grujicic, M., Zhao, C. L., DeRosset W. S., Helfritch, D. Adiabatic shear instability based mechanism for particles/substrate bonding in the coldgas dynamic-spray process, Mater. Des. 25 (2004) 681688. https://doi.org/10.1016/j.matdes.2004.03.008.

[20] Bae, G., Xiong, Y., Kumar, S., Kang, K., Lee, G., General aspects of interface bonding in kinetic sprayed coatings, Acta Mater. 56 (2008) 4858-4868. https://doi.org/10.1016/j.actamat.2008.06.003.

[21] King, P. C, Busch, C., Kittel-Sherri, T., Jahedi, M., Gulizia, S., Interface melding in cold spray titanium particle impact, Surf. Coatings Technol. 239 (2014) 191-199.

10.1016/j.surfcoat.2013.11.039.

[22] Schmidt, T., Assadi, H., Gärtner, F., Richter, H., Stoltenhoff, T., Kreye, H., Klassen, T. From particle acceleration to impact and bonding in cold spraying, J. Therm. Spray Technol. 18 (2009) 794-808. https://doi.org/10.1007/s11666-009-9357-7.

[23] H. Assadi, H., Schmidt, T., Richter, H., Kliemann, J.-O., Binder, K., Gärtner, F., Klassen, T., Kreye, H., On Parameter Selection in Cold Spraying, J. Therm. Spray Technol. 20 (2011) 1161-1176. https://doi.org/ 10.1007/s11666-011-9662-9.

[24] Li, C.-J., Li, W.-Y., Liao, H., Examination of the Critical Velocity for Deposition of Particles in Cold
Spraying, J. Therm. Spray Technol., 15 (2006) 212-222. https://doi.org/ 10.1361/105996306X108093.

[25] Sun, C., Guo, L., GuanxiongLu, G., Lv, Y., Ye, F. Interface bonding between particle and substrate during HVOF spraying, Appl. Surf. Sci. 317 (2014) 908-913. https://doi.org/10.1016/J.APSUSC.2014.08.196.

[26] Yin, S., Xie, Y., Suo, X., Liao, H., Wang, X. Interfacial bonding features of $\mathrm{Ni}$ coating on $\mathrm{Al}$ substrate with different surface pretreatments in cold

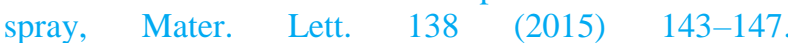
https://doi.org/10.1016/j.matlet.2014.10.016.

[27] Suegama, P. H.; Fugivara, C. S; Benedetti, A. V.; Fernández, J.; Espallargas, N.; Delgado, J., Guilemany, J. M. New Research on Electrochemistry, in: Nova Science Publishers, 2007: pp. 113-151.

[28] Li, W. Y., Zhang, C., Guo, X. P., Zhang, G., Liao, H. L., Li, C. J., Coddet, C. Effect of standoff distance on coating deposition characteristics in cold spraying, Mater. $\quad$ Des. $29 \quad$ (2008) 297-304. https://doi.org/10.1016/j.matdes.2007.02.005.

[29] Li, C.-J., Li, W.-Y., Wang, Y.-Y., Effect of Spray Angle on Deposition Characteristics in Cold Spraying, Advancing the Science \& Applying the Technology, (Ed.) C. Moreau and B. Marple, ASM International, Materials Park, Ohio, 2003, 91-96.

[30] Ernst, K.-R., Braeutigam, J., Gärtner, F., Klassen, T., Effect of Substrate Temperature on Cold-GasSprayed Coatings on Ceramic Substrates, J. Therm. Spray Technol. 22 (2012) 422-432. https://doi.org/ 10.1007/s11666-012-9871-x.

[31] Kay, C. M, Karthikeyan, J. High Pressure Cold Spray, ASM International, 2016.

[32] German, R. M., Powder metallurgy and particulate materials processing, Metal Powder Industry, Princeton, 2005 .

[33] Lagutkin, S., Achelis, L., Sheikhaliev, S., Uhlenwinkel, V., Srivastava, V. Atomization process for metal powder, Materials Sci. Eng.: A, 383 (2004) 16. https://doi.org/10.1016/j.msea.2004.02.059.

[34] Powder production - LPW Technology. http://www.lpwtechnology.com/technicallibrary/powder-production/ (accessed November 23, 2017).

[35] Dosta, S., Couto, M., Guilemany, J. M. Cold spray deposition of a WC-25Co cermet onto Al7075-T6 and carbon steel substrates, Acta Mater. 61 (2013) 643-652. https://doi.org/10.1016/j.actamat.2012.10.011. 
[36] Couto, M., Dosta, S., Fernández, J., Guilemany, J. M. Comparison of the Mechanical and Electrochemical Properties of WC-25Co Coatings Obtained by High Velocity Oxy-Fuel and Cold Gas Spraying, J. Therm. Spray Technol. 23 (2014) 1251-1258. https://doi.org/10.1007/s11666-014-0123-0.

[37] Berger, L.-M. Hardmetals as thermal spray coatings, Powder Metall. 50 (2007) 205-214. https://doi.org/10.1179/174329007X246078.

[38] Shin, H., Lee, S. Suk, Jung, H., Kim, J. B. Effect of ball size and powder loading on the milling efficiency of a laboratory-scale wet ball mill, Ceram. Int. 39 (2013) 8963-8968. https://doi.org/10.1016/j.ceramint.2013.04.093.

[39] Tangsathitkulchai, C. Acceleration of particle breakage rates in wet batch ball milling, Powder Technol. $124 \quad$ (2002) 67-75. https://doi.org/10.1016/S0032-5910(01)00477-6.

[40] Villafuerte J. Modern cold spray: materials, process, and applications, Springer International Publishing, 2015.

[41] Moridi, A., Hassani-Gangaraj, S. M., Guagliano, M., Dao, M. Cold spray coating: review of material systems and future perspectives, Surf. Eng. 36(6) (2014) 369-395.

https://doi.org/10.1179/1743294414Y.0000000270.

[42] Robotti, M., Dosta, S., Fernández-Rodríguez, C., Hernández-Rodríguez, M. J., Cano, I. G., Melián, E. P., Guilemany, J. M. Photocatalytic abatement of NOx by C-TiO2/polymer composite coatings obtained by low pressure cold gas spraying, Appl. Surf. Sci. 362 (2016) 274-280. https://doi.org/10.1016/j.apsusc.2015.11.207.

[43] Cold gas spray (CGS), Communications material, Thermal Spray Center.

[44] Cinca, N., Rebled, J. M., Estradé, S., Peiró, F., Fernández, J., Guilemany, J. M., Influence of the particle morphology on the Cold G Spray deposition behavior of titanium on aluminum light alloys, J. Alloys Compd. $\quad 554 \quad$ (2013) 89-96. https://doi.org/10.1016/j.allcom.2012.11.069.

[45] About Cold Gas Spraying and overview systems, Duiven. https://www.fst.nl/systems/cold-gas-spray/ (accessed October 24, 2017).

[46] Li, W.-Y., Liao, H., Douchy, G., Coddet, C., Optimal design of a cold spray nozzle by numerical analysis of particle velocity and experimental validation with 316L stainless steel powder, Mater. Des. 28 (2007) 2129-2137.

https://doi.org/10.1016/j.matdes.2006.05.016.
[47] Silva, F. S. da, Bedoya, J., Dosta, S., Cinca, N., Cano, I. G., Guilemany, J. M., Benedetti, A. V. Corrosion characteristics of cold gas spray coatings of reinforced aluminum deposited onto carbon steel, $\begin{array}{lllll}\text { Corros. } & \text { Sci. } & 114 & \text { (2017) } & \text { 57-71. }\end{array}$ https://doi.org/10.1016/j.corsci.2016.10.019.

[48] Richer, P., Jodoin, B., Ajdelsztajn, L., Lavernia, E. J. Substrate Roughness and Thickness Effects on Cold Spray Nanocrystalline Al-Mg Coatings, J. Therm. Spray Technol. $\quad 15 \quad$ (2006) 246-254 https://doi.org/10.1361/105996306X108174.

[49] Metal/ Environment Reactions, NewnesButterworth, 2nd edition, 1976.

[50] Bai, Y., Wang, Z. H., Li, X. B., Huang, G. S., Li, C., X. Li, Y. Corrosion behavior of low pressure cold sprayed $\mathrm{Zn}-\mathrm{Ni}$ composite coatings, J. Alloys Compd. 719 (2017) 194-202. https://doi.org/10.1016/j.jallcom.2017.05.134.

[51] Suna, W., Tan, A. W., Y., Marinescu, I., Toh, W. Q., Liu, E. Adhesion, tribological and corrosion properties of cold-sprayed CoCrMo and Ti6Al4V coatings on 6061-T651 Al alloy, Surf. Coatings Technol. $\quad 326 \quad$ (2017) 291-298. https://doi.org/10.1016/J.SURFCOAT.2017.07.062.

[52] Diab, M., Pang X., Jahed, H. The effect of pure aluminum cold spray coating on corrosion and corrosion fatigue of magnesium ( $3 \% \mathrm{Al}-1 \% \mathrm{Zn}$ ) extrusion, Surf. Coatings Technol. $309 \quad$ (2017) 423-435. https://doi.org/10.1016/J.surfcoat.2016.11.014.

[53] Y. Tao, T. Xiong, C. Sun, L. Kong, X. Cui, T. Li, G.L. Song, Microstructure and corrosion performance of a cold sprayed aluminium coating on AZ91D magnesium alloy, Corros. Sci. 52 (2010) 3191-3197. https://doi.org/10.1016/j.corsci.2010.05.023.

[54] Khun, N. W., Tan, A., W. Y., Sun, W., Liu, E. Wear and Corrosion Resistance of Thick Ti-6Al-4V Coating Deposited on Ti-6Al-4V Substrate via HighPressure Cold Spray, J. Therm. Spray Technol. 26 (2017) 1393-1407. https://doi.org/10.1007/s11666-0170588-8.

[55] Chavan, N. M., Kiran, B., Jyothirmayi, A., Phani, P. S., Sundararajan, G., The corrosion behavior of cold sprayed zinc coatings on mild steel substrate, J. Therm. $\begin{array}{lllll}\text { Spray } & \text { Technol. } & 22 & \text { (2013) 463-470. }\end{array}$ https://doi.org/10.1007/s11666-013-9893-z.

[56] Zhu, Q. J., Wang, K., Wang, X. H., Hou, B. R. Electrochemical impedance spectroscopy analysis of cold sprayed and arc sprayed aluminium coatings serviced in marine environment, Surf. Eng. 28 (2012) 
300-305.

https://doi.org/10.1179/1743294411Y.0000000036.

[57] DeForce, B. S., Eden, T. J., Potter, J. K., Cold Spray Al-5\% Mg Coatings for the Corrosion Protection of Magnesium Alloys, J. Therm. Spray Technol. 20 (2011) 1352-1358. https://doi.org/10.1007/s11666-0119675-4.

[58] Wang, H. R., Hou, B. R., Wang, J., Wang, Q., Li, W. Y., Effect of process conditions on microstructure and corrosion resistance of cold-sprayed Ti coatings, J. Therm. Spray Technol. 17 (2008) 736-741. https://doi.org/10.1007/s11666-008-9256-3.

[59] Kumar, S., Vidyasagar, V., Jyothirmayi, A., Joshi, S. V. Effect of Heat Treatment on Mechanical Properties and Corrosion Performance of Cold-Sprayed Tantalum Coatings, J. Therm. Spray Technol. 25 (2016) 745-756. https://doi.org/10.1007/s11666-016-0388-6.

[60] Sundararajan, G., Sudharshan Phani, P., Jyothirmayi, A., Gundakaram, R. C., The influence of heat treatment on the microstructural, mechanical and corrosion behaviour of cold sprayed SS 316L coatings, J. Mater. Sci. 44 (2009) 2320-2326. https://doi.org/10.1007/s10853-008-3200-2.

[61] Ma, C., Liu, X., Zhou, C. Cold-Sprayed Al Coating for Corrosion Protection of Sintered NdFeB, J. Therm. Spray Technol. $23 \quad$ (2014) 456-462. https://doi.org/10.1007/s11666-013-9994-8.

[62] Spencer, K., Zhang, M. X. Optimisation of stainless steel cold spray coatings using mixed particle size distributions, Surf. Coatings Technol. 205 (2011) 5135-5140.

https://doi.org/10.1016/J.SURFCOAT.2011.05.020.

[63] Zhou, X., Mohanty, P. Electrochemical behavior of cold sprayed hydroxyapatite/titanium composite in Hanks' solution, Electrochim. Acta. 65 (2012) 134-140. https://doi.org/10.1016/j.electacta.2012.01.018.

[64] Diab, M., Pang, X., Jahed, H. The effect of pure aluminum cold spray coating on corrosion and corrosion fatigue of magnesium ( $3 \% \mathrm{Al}-1 \% \mathrm{Zn})$ extrusion, Surf.

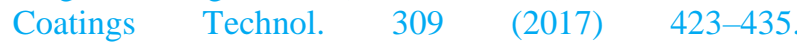
https://doi.org/10.1016/j.surfcoat.2016.11.014.

[65] Rokni, M. R, Widener, C. A., Champagne, V. K., Crawford, G.A., Nutt, S.R. The effects of heat treatment on 7075 Al cold spray deposits, Surf. Coatings Technol. $310 \quad$ (2017) 278-285. https://doi.org/10.1016/J.SURFCOAT.2016.10.064.

[66] Rokni, M. R., Widener, C. A., Ozdemir, O. C., Crawford, G. A. Microstructure and mechanical properties of cold sprayed $6061 \mathrm{Al}$ in As-sprayed and heat treated condition, Surf. Coatings Technol. 309 (2017)

$641-650$.

https://doi.org/10.1016/J.SURFCOAT.2016.12.035

[67] Kumar, S., KiranReddy, S., Joshi, S. V. Microstructure and performance of cold sprayed Al-SiC composite coatings with high fraction of particulates, Surf. Coatings Technol. 318 (2017) 62-71. https://doi.org/10.1016/J.SURFCOAT.2016.11.047.

[68] Watson, T. J., Nardi, A., Ernst, A. T., Cernatescu, I., Bedard, B. A., Aindow, M. Cold spray deposition of an icosahedral-phase-strengthened aluminum alloy coating, Surf. Coatings Technol. 324 (2017) 57-63. https://doi.org/10.1016/J.SURFCOAT.2017.05.049.

[69] Meydanoglu, O., Jodoin, B., Kayali, E. S. Surface \& Coatings Technology Microstructure, mechanical properties and corrosion performance of $7075 \mathrm{Al}$ matrix ceramic particle reinforced composite coatings produced by the cold gas dynamic spraying process, Surf. Coat. Technol. 235 (2013) 108-116. https://doi.org/10.1016/j.surfcoat.2013.07.020.

[70] Morgan, R., Fox, P., Pattison, J., Sutcliffe, C., Neill, W. O. Analysis of cold gas dynamically sprayed aluminium deposits, Mater. Lett. 58 (2004) 1317-1320. https://doi.org/10.1016/j.matlet.2003.09.048.

[71] Rech, S., Trentin, A., Vezzù, S., Vedelago, E., Legoux, J.-G., Irissou, E., Different Cold Spray Deposition Strategies: Single- and Multi-layers to Repair Aluminium Alloy Components, J. Therm. Spray Technol. $6061 \quad$ (2014) 1237-1250. https://doi.org/10.1007/s11666-014-0141-y.

[72] Ogawa, K., Ito, K., Ichimura, K., Ichikawa, Y., Ohno, S., Onda, N., Characterization of low-pressure cold-sprayed aluminum coatings, J. Therm. Spray $\begin{array}{llll}\text { Technol. } & 17 & \text { (2008) }\end{array}$ https://doi.org/10.1007/s11666-008-9254-5.

[73] Spencer, K., Fabijanic, D. M., Zhang, M. X., The use of $\mathrm{Al}-\mathrm{Al} 2 \mathrm{O} 3$ cold spray coatings to improve the surface properties of magnesium alloys, Surf. Coatings Technol. $204 \quad$ (2009) 336-344. https://doi.org/10.1016/j.surfcoat.2009.07.032.

[74] Bakshi, S. R., Wang, D., Price, T., Zhang, D., Keshri, A. K., Chen, Y., McCartney, D. G., Shipway, P. H., Agarwal, A. Microstructure and wear properties of aluminum/aluminum-silicon composite coatings prepared by cold spraying, Surf. Coatings Technol. 204 (2009) $503-510$ https://doi.org/10.1016/j.surfcoat.2009.08.018.

[75] Bu, H., Yandouzi, M., Lu, C., Jodoin, B., Post-heat treatment effects on cold-sprayed aluminum coatings on AZ91D magnesium substrates, J. Therm. Spray 
Technol. 21

(2012)

$731-739$

https://doi.org/10.1007/s11666-012-9785-7.

[76] Legoux, J. G., Irissou, E., Moreau, C. Effect of Substrate Temperature on the Formation Mechanism of Cold-Sprayed Aluminum, Zinc and Tin Coatings, J. Therm. Spray Technol. 16 (2007) 619-626. https://doi.org/10.1007/s11666-007-9091-y.

[77] Hall, A. C., Brewer, L. N., Roemer, T. J., Preparation of aluminum coatings containing homogenous nanocrystalline microstructures using the cold spray process, J. Therm. Spray Technol. 17 (2008) 352-359. https://doi.org/10.1007/s11666-008-9180-6.

[78] Hall, A. C., Cook, D. J., Neiser, R. A., Roemer, T. J., Hirschfeld, D. A. The Effect of a Simple Annealing Heat Treatment on the Mechanical Properties of ColdSprayed Aluminum, J. Therm. Spray Technol. 15 (2006) 233-238. https://doi.org/10.1361/105996306X108138.

[79] Tao, Y., Xiong, T., Sun, C., Jin, H., Du, H., Li, T., Effect of $\alpha$-Al2O3 on the properties of cold sprayed $\mathrm{Al} / \alpha-\mathrm{A} 12 \mathrm{O} 3$ composite coatings on AZ91D magnesium alloy, Appl. Surf. Sci. 256 (2009) 261-266. https://doi.org/10.1016/j.apsusc.2009.08.012.

[80] Bakshi, S. R., Laha, T., Balani, K., Agarwal, A., Karthikeyan, J. Effect of carrier gas on mechanical properties and fracture behaviour of cold sprayed aluminium coatings, Surf. Eng. 23 (2007) 18-22. https://doi.org/10.1179/174329407X161618.

[81] Ajdelsztajn, L., Zúñiga, A., Jodoin, B., Lavernia, E. J. Cold gas dynamic spraying of a high temperature Al alloy, Surf. Coatings Technol. 201 (2006) 2109_ 2116. https://doi.org/10.1016/j.surfcoat.2005.06.001.

[82] Lahiri, D., Gill, P. K., Scudino, S., Zhang, C., Singh, V., Karthikeyan, J., Munroe, N., Seal, S., Agarwal, A. Cold sprayed aluminum based glassy coating: Synthesis, wear and corrosion properties, Surf.

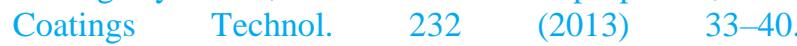
https://doi.org/10.1016/j.surfcoat.2013.04.049.

[83] Dzhurinskiy, D., Maeva, E., Leshchinsky, E., Maev, R. G. Corrosion protection of light alloys using low pressure cold spray, J. Therm. Spray Technol. 21 (2012) 304-313. https://doi.org/10.1007/s11666-0119729-7.

[84] Sharma, M. M., Eden, T. J., Golesich, B. T. Effect of Surface Preparation on the Microstructure, Adhesion, and Tensile Properties of Cold-Sprayed Aluminum Coatings on AA2024 Substrates, J. Therm. Spray Technol. 24 (2014) 410-422. https://doi.org/10.1007/s11666-014-0175-1.
[85] Rokni, M. R., Widener, C. A., Champagne, V. R. Microstructural Evolution of 6061 Aluminum GasAtomized Powder and High-Pressure Cold-Sprayed Deposition, J. Therm. Spray Technol. 23 (2013) 514524. https://doi.org/10.1007/s11666-013-0049-y.

[86] Jodoin, B., Ajdelsztajn, L., Sansoucy, E., Zúñiga, A., Richer, P., Lavernia, E. J. Effect of particle size, morphology, and hardness on cold gas dynamic sprayed aluminum alloy coatings, Surf. Coatings Technol. 201 (2006) $3422-3429$ https://doi.org/10.1016/j.surfcoat.2006.07.232.

[87] Ziadi, A., Belzunce, F. J., Rodriguez, C. The effects of heat treatment on the mechanical properties of multicomponent white cast irons, J. Mater. Sci. (2007). https://doi.org/10.1007/s10853-006-1448-y.

[88] Ngai, S., Ngai, T., Vogel, F., Story, W., Thompsom, G. B.; Brewer, L. N. Saltwater corrosion behavior of cold sprayed AA7075 aluminum alloy coatings, Corros. Sci. 130 (2018) 231-240. https://doi.org/10.1016/J.CORSCI.2017.10.033.

[89] McCafferty, E. Sequence of steps in the pitting of aluminum by chloride ions, Corros. Sci. 45 (2003) 1421-1438. https://doi.org/10.1016/S0010938X(02)00231-7.

[90] Hassani-Gangaraj, S. M., Moridi, A., Guagliano, M. Critical review of corrosion protection by cold spray coatings, Surf. Eng. 31 (2015) 803-815. https://doi.org/10.1179/1743294415Y.0000000018.

[91] Silva, F. S. da, Dosta, S., Cano, I. G., Couto, M., Guilemany, J. M., Benedetti, A. V. Corrosion behavior of WC-Co coatings deposited by Cold Gas Spray onto Al 7075-T6, Corr. Sci., 2017 submitted.

[92] Silva, F. S. da, Dosta, S., Zomeño, K., Cinca, N., Cano, I. G., Couto, M., Guilemany, J. M., Benedetti, A. $\mathrm{V}$. Influence of different copper feedstock powders on the microstructure and corrosion of coatings prepared by cold gas spray, Corr. Sci., 2017 submitted.

[93] Huang, R., Sone, M., Ma, W., Fukanuma, H. The effects of heat treatment on the mechanical properties of cold-sprayed coatings, Surf. Coatings Technol. 261 (2015) 278-288. https://doi.org/10.1016/J.SURFCOAT.2014.11.017.

[94] Gärtner, F., Stoltenhoff, T., Voyer, J., Kreye, H., Riekehr, S., Koçak, M. Mechanical properties of coldsprayed and thermally sprayed copper coatings, Surf. Coatings Technol. $200 \quad$ (2006) 6770-6782. https://doi.org/10.1016/J.SURFCOAT.2005.10.007.

[95] Arabgol, Z., Assadi, H., Schmidt, T., Gärtner, F., Klassen, T. Analysis of Thermal History and Residual 
Stress in Cold-Sprayed Coatings, J. Therm. Spray Technol. $\quad 23 \quad$ (2014) 84-90. https://doi.org/10.1007/s11666-013-9976-X.

[96] Hall, A. C., Cook, D. J., Neiser, R. A., Roemer, T. J., Hirschfeld, D. A. The Effect of a Simple Annealing Heat Treatment on the Mechanical Properties of ColdSprayed Aluminum, J. Therm. Spray Technol. 15 (2006) 233-238.

https://doi.org/10.1361/105996306X108138.

[97] Bu, H., Yandouzi, M., Lu, C., Jodoin, B. Post-heat Treatment Effects on Cold-Sprayed Aluminum Coatings on AZ91D Magnesium Substrates, J. Therm. Spray $\begin{array}{llll}\text { Technol. } & 21 & \text { (2012) 731-739. }\end{array}$ https://doi.org/10.1007/s11666-012-9785-7.

[98] Sudharshan Phani, P., Srinivasa Rao, D., Joshi, S.V., Sundararajan, G. Effect of Process Parameters and Heat Treatments on Properties of Cold Sprayed Copper Coatings, J. Therm. Spray Technol. 16 (2007) 425-434. https://doi.org/10.1007/s11666-007-9048-1.

[99] Li, W.-Y., Li, C.-J., Liao, H., Effect of Annealing Treatment on the Microstructure and Properties of ColdSprayed $\mathrm{Cu}$ Coating, J. Therm. Spray Technol. 15 (2006)

206-211.

https://doi.org/10.1361/105996306X108066.

[100] Meng, X. M., Zhang, J. B., Han, W., Zhao, J. Influence of annealing treatment on cold rolling behaviour of 304SS coating by cold spraying, Mater. Res. Innov. $16 \quad$ (2012) 73-78. https://doi.org/10.1179/1433075X11Y.0000000018.

[101] Wong, W., Irissou, E., Vo, P., Sone, M., Bernier, F., Legoux, J.-G., Fukanuma, H., Yue, S., Cold Spray Forming of Inconel 718, J. Therm. Spray Technol. 22 (2013) 413-421. https://doi.org/10.1007/s11666-0129827-1.

[102] Sajjadi, S. A., Ezatpour, H. R., Beygi, H. Microstructure and mechanical properties of $\mathrm{Al}-\mathrm{A} 12 \mathrm{O} 3$ micro and nano composites fabricated by stir casting, Mater. Sci. Eng. A. 528 (2011) 8765-8771. https://doi.org/10.1016/j.msea.2011.08.052.

[103] Miyajima, T., Iwai, Y., Effects of reinforcements on sliding wear behavior of aluminum matrix composites, Wear. $255 \quad$ (2003) 606-616. https://doi.org/10.1016/S0043-1648(03)00066-8.

[104] Kim, H. J., Lee, C. H., Hwang, S. Y., Superhard nano WC-12\%Co coating by cold spray deposition, Mater. Sci. Eng. A. 391 (2005) 243-248. https://doi.org/10.1016/j.msea.2004.08.082.

[105] Peat, T., Galloway, A., Toumpis, A., Steel, R., Zhu, W., Iqbal, N. Enhanced erosion performance of cold spray co-deposited AISI316 MMCs modified by friction stir processing, Mater. Des. 120 (2017) 22-35. https://doi.org/10.1016/j.matdes.2017.01.099.

[106] Triantou, K. I., Pantelis, D. I., Guipont, V., Jeandin, M. Microstructure and tribological behavior of copper and composite copper+alumina cold sprayed coatings for various alumina contents, Wear. 336-337 (2015) 96-107. https://doi.org/10.1016/J.WEAR.2015.05.003.

[107] Phani, P. S., V.Vishnukanthan, V., Sundararajan, G. Effect of heat treatment on properties of cold sprayed nanocrystalline copper alumina coatings, Acta Mater. 55 (2007) 4741-4751. https://doi.org/10.1016/J.ACTAMAT.2007.04.044.

[108] Assadi, H., Kreye, H., Gärtner, F., Klassen, T. Cold spraying - A materials perspective, Acta Mater. 116 (2016), 382-407. https://doi.org/ 10.1016/j.actamat.2016.06.034.

[109] Partovi-Nia, R., Ramamurthy, S., Zagidulin, D. J. Chen, R. Jacklin, P. Keech, D.W. Shoesmith, Corrosion of Cold Spray Deposited Copper Coating on Steel Substrates, Corrosion. 71 (2015) 1237-1247. https://doi.org/10.5006/1757.

[110] Rokni, M. R, Nutt, S. R., Widener, C. A., Champagne, V. K., Hrabe, R. H. Review of Relationship Between Particle Deformation-Coating Microstructure and Properties in High Pressure Cold Spray. J. Therm. Spray Technol. (2017) 1-40. https://doi.org/10.1007/s11666-017-0575-0.

[111] Cinca, N., Barbosa, M., Dosta, S., Guilemany, J. M. Study of Ti deposition onto Al alloy by cold gas spraying, Surf. Coatings Technol. 205 (2010) 10961102. https://doi.org/10.1016/j.surfcoat.2010.03.061.

[112] Kear, G., Barker, B. D., Stokes, K., Walsh, F. C. Electrochemical Corrosion Behaviour of 90-10 $\mathrm{Cu}-\mathrm{Ni}$ Alloy in Chloride-Based Electrolytes, J. Appl. Electrochem. $\quad 34 \quad$ (2004) 659-669. https://doi.org/10.1023/B:JACH.0000031164.32520.58.

[113] Koivuluoto, H., Bolelli, G., Lusvarghi, L., Casadei, F., Vuoristo, P. Corrosion resistance of coldsprayed Ta coatings in very aggressive conditions, Surf. Coatings Technol. $205 \quad$ (2010) 1103-1107. https://doi.org/10.1016/J.SURFCOAT.2010.02.052.

[114] Henao, J., Concustell. A., Dosta, S., G.Bolelli, G., Cano, I. G., Lusvarghi, L., Guilemany, J. M. Deposition mechanisms of metallic glass particles by Cold Gas Spraying, Acta Mater. 125 (2017) 327-339. https://doi.org/10.1016/J.ACTAMAT.2016.12.007. 
[115] Wang, Y., Normand, B., Mary, N., Yu, M., Liao, H. Microstructure and corrosion behavior of cold sprayed SiCp/Al 5056 composite coatings, Surf. $\begin{array}{lllll}\text { Coatings } & \text { Technol. } & 251 & \text { (2014) 264-275. }\end{array}$ https://doi.org/10.1016/J.SURFCOAT.2014.04.036.

[116] Koivuluoto, H., Lagerbom, J., Vuoristo, P. Microstructural studies of cold sprayed copper, nickel, and nickel-30\% copper coatings, J. Therm. Spray

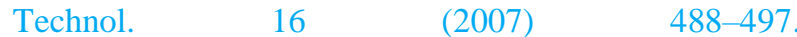
https://doi.org/10.1007/s11666-007-9060-5.

[117] Oliveira, A. B., Bastos, A. C., Fernandes, C. M., Pinho, C. M. S., Senos, A. M. R., Soares, E., Sacramento, J., Zheludkevich, M. L. Ferreira, M.G.S. Corrosion behaviour of WC-10\% AISI 304 cemented carbides, Corros. Sci. 100 (2015) 322-331. https://doi.org/10.1016/j.corsci.2015.08.006.

[118] Wolfe, D. E., Eden, T. J., Potter, J. K., Jaroh, A. $\mathrm{P}$., Investigation and characterization of $\mathrm{Cr} 3 \mathrm{C} 2$-based wear-resistant coatings applied by the cold spray process, J. Therm. Spray Technol. 15 (2006) 400-412. https://doi.org/10.1361/105996306X124400.

[119] Vucko, M. J., King, P. C., Poole, A. J., Carl, C., Jahedi, M. Z., de Nys, R., Cold spray metal embedment: an innovative antifouling technology., Biofouling. 28 (2012)

https://doi.org/10.1080/08927014.2012.670849. 239-48.

[120] Vucko, M. J., King, P. C., Poole, A. J., Hu, Y., Jahedi, M. Z., de Nys, R., Assessing the antifouling properties of cold-spray metal embedment using loading density gradients of metal particles., Biofouling. 30 (2014) $651-66$ https://doi.org/10.1080/08927014.2014.906584.

[121] Feng, C., Guipont, V., Jeandin, M., Amsellem, O., Pauchet, F., Saenger, R., Bucher, S., Iacob, C. B4C/Ni Composite Coatings Prepared by Cold Spray of Blended or CVD-Coated Powders, J. Therm. Spray Technol. 21 (2012) 561-570. https://doi.org/10.1007/s11666-0129774-X.

[122] Vilardell, A. M., Cinca, N., Cano, I. G., Concustell, A., Dosta, S., Guilemany, J. M., Estradé, S., Ruiz-Caridad, A., Peiró, F. Dense nanostructured calcium phosphate coating on titanium by cold spray, J. Eur. Ceram. Soc. 37 (2017) 1747-1755. https://doi.org/10.1016/j.jeurceramsoc.2016.11.040.

[123] Bakshi, S. R., Singh, V., Balani, K., McCartney, D.G., Seal, S., Agarwal, A. Carbon nanotube reinforced aluminum composite coating via cold spraying, Surf. Coatings Technol. $202 \quad$ (2008) 5162-5169. https://doi.org/10.1016/j.surfcoat.2008.05.042.
[124] Lee, H. Y., Yu, Y. H., Lee, Y. C., Hong, Y. P., Ko, K. H. Cold Spray of $\mathrm{SiC}$ and Al2O3 with Soft Metal Incorporation: A Technical Contribution, J. Therm. Spray Technol. 13 (2004) 184-189. https://doi.org/10.1361/10599630419355.

[125] Wang, Y., Normand, B., Mary, N., Yu, M., Liao, $\mathrm{H}$. Effects of ceramic particle size on microstructure and the corrosion behavior of cold sprayed SiCp/Al 5056 composite coatings, Surf. Coatings Technol. 315 (2017) 314-325.

https://doi.org/10.1016/j.surfcoat.2017.02.047.

[126] Hodder, K. J., Nychka, J. A., McDonald, A. G. Comparison of $10 \mu \mathrm{m}$ and $20 \mathrm{~nm} \mathrm{Al-Al2O}$ Metal Matrix Composite Coatings Fabricated by Low-Pressure Cold Gas Dynamic Spraying, J. Therm. Spray Technol. 23 (2014) 839-848. https://doi.org/10.1007/s11666-0140094-1.

[127] Bush, T. B., Khalkhali, Z., Champagne, V., Schmidt, D. P., Rothstein, J. P. Optimization of Cold Spray Deposition of High-Density Polyethylene Powders, J. Therm. Spray Technol. 26 (2017) 15481564. https://doi.org/10.1007/s11666-017-0627-5

[128] Ichikawa, Y., Ogawa, K., Nonaka, I. HighTemperature Oxidation Behavior of Cold-Sprayed MCrAlY Coatings, J. Soc. Mater. Sci. Japan. 60 (2011) 159-166. https://doi.org/10.2472/jsms.60.159.

[129] Cinca, N. Guilemany, J. M. Thermal spraying of transition metal aluminides: An overview, Intermetallics. $\quad 24 \quad$ (2012) 60-72. https://doi.org/10.1016/j.intermet.2012.01.020.

[130] Luo, X. T., Li, C. X., Shang, F. L., Yang, G. J., Wang, Y. Y., Li, C. J. WC-Co Composite Coating Deposited by Cold Spraying of a Core-Shell-Structured WC-Co Powder, J. Therm. Spray Technol. 24 (2014) 100-107. https://doi.org/10.1007/s11666-014-0133-y.

[131] Kim, H. J., Lee, C. H., Hwang, S.Y. Fabrication of WC-Co coatings by cold spray deposition, Surf. Coatings Technol. 191 (2005) 335-340. https://doi.org/10.1016/j.surfcoat.2004.04.058. 